\title{
NÃO É UM MITO A ESCOLÁ NÁUTICA CRIADA E MANTIDA PELO INFANTE D. HENRIQUE EM TERRA ALGARVIA.
}

O tex' $\Omega$ que adiante se apresenta foi elaborado durante $\mathrm{c}$ primeiro semestre de 1957 para eventual publicação na "Revista de História". Submetido logo depois à apreciação crítica do sr. Dr. Joaquim Alberto Iria, ilustre e proficiente Diretor do Arquivo Histórico Ultramarino, de Lisboa, e mui distinto historiógrafo, foi por êle gabado em têrmos, para mim, assaz desvanecedores. Com bom augúrio, pois, me atreveria eu a remetê-lo ao sr. Prof. Dr. Eurípedes Simões de Paula se algo de nôvo não me tivesse feito suspender o intento. E' que se projetavam então em Portugal as comemorações do quinto centenário da morte do Infante D. Henrique e em tais comemorações incluia-se a realização em Lisboa de um Congresso Internacional de História dos Descobrimentos, ao qual me interessava muito assistir, como curioso, que sou, dos temas que ali se jriam debater. Conservando, pois, inédito o texto em referência, poderia apresentá-lo a tão notável areópago como comunicação que lhe cumpriria discutir, e isso foi o que eu acabei por fazer.

Para não me tornar demasiado enfadonho, direi arenas que - Congresso teve a sua realização de 6 a 11 de setembro de 1960. A minha comunicação, distribuída à 2a. Subsecção da 1a. Secção, onde se versavam temas relacionados com a ciência náutica, foi discutida em sessão do dia 7 de setembro e. pela oposição que lhe moveu o relator - pessoa de alto nível cultural, mas que, sôbre a matéria em causa, professa pontos de vista fundados em suposições suas e alheias, e não em razões náuticas de validade indiscutível —, não terá, certamente, obtido parecer favorável para figurar entre as que o Secretariado Geral do Congresso dará à estampa. Por isso, e para que os leitores da "Revista de História" possam julgar o mér:to ou demérito dêsse meu trabalho, remeto-o ao destino que primitivamente lhe havia reservado, ou seja ao sr. Prof. Dr. Eurípe- 
des Simões de Paula, de cuja inteireza e magnanimidade sempre recebi mercê.

Ao trabalho, tal como foi apresentado ao sobredito Congresso, seguem-se as considerações por mim aduzidas em sua defesa e as objeções que lhe foram opostas pelo referido relator e por um outro congressista. A essas objeções seguem-se ainda as minhas respostas, as quais não foram emitidas diante dos meus contraditores porque, embora considerando eu fastidioso e vão tentar convencer quem a tanto se negava, disso teria sido impedido por motivo alheio à minha vontade, pois a sessão em referência foi encerrada mal o meu último opositor se havia calado.

E não alongo mais êste preâmbulo. Apresento, a seguir, o texto em questão. Modesto, sim, mas elaborado com honestidade e consciência.

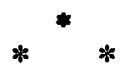

Depois de passado meio milênio sôbre o falecimento do Infante $\mathrm{D}$. Henrique poder-se-ia supor que a áura glorificadora dêste ínclito filho de D. João I continua a fulgir com invariável magnitude. Figura histórica de primeira grandeze, iricontestável iniciador do movimento português dos descob,rimentos marítimos, não falta, porém, quem ache exagerados e até fantasiosos alguns dos méritos que se lhe atribuem, tais como, por exemplo, o de haver estabelecido e patrocinado uma escola de navegação em terra algarvia. Apurado que a chamada Escola de Sagres não foi um fato histórico mas antes invencionice de um qualquer panegirista do Infante, logo se passou a proclamar e a repetir urbi et orbi que "a escola náutica daquela época era no mar, vivendo a bordo de navios em íntima e plena promiscuidade com velhas e adestradas tripulações". E assim se tem tratado de despojar a memória do Infante de um dos lauréis que mais a enaltecem!

Ora nós, vulgar calcorriador dos caminhos do mar um pouco dado ao estudo dos problemas técnico-náuticos dos Descobrimentos, temos como fato verídico a existência de uma escola de cosmografia, cartografia e marinharia em terra algarvia no tempo do Infante D. Henrique. Cônscio de que é acertado o parecer do falecido comandante Fontoura da Costa (1), diremos, como êle, que essa escola não funcionou em Sagres, mas sim em Lagos, que era, afinal, o pôrto de onde partiam e

(1). - Vide: A Marinharia dos Descobrimentos, Lisboa, 1939, págs. 11-12. 
onde regressavam os caravelistas henriquinos. Embora reconhecendo as nossas limitações de homem do mar, não deixaremos de sustentar uma tal verdade, e isso porque ela é comprovada, se não por documentos dimanados do Infante ou de outras fontes portuguêsas da época, ao menos pela-evidência de vários fatos concretos, entre os quais avulta, sem dúvida, o dos navegadores henriquinos saberem representar cartogràficamente a situação, as conhecenças e os delineamentos costeiros das terras que iam descobrindo.

Em que nível de melhoria estaria a ciência náutic: partuguêses nos primeiros anos de século XV?... Não estava, com certeza, mais evoluída do que a dos espanhóis um século depois. E', porém, incontestável que já na terceira década daquele século sabiam os navegadores portuguêses como demandar, com segurança e acêrto, qualquer objetivo no mar largo, e isso, evidentemente, porque em sua formação profissional se aliavam os ensinamentos teóricos de cosmegrafia e marinharia, recebidos em escola, com a prática do mar adquirida a bordo dos navios.

Ao nosso grande Pedro Nunes, que foi cosmọgrafo-mor e examinador de pilotos, não faltava autoridade para escrever em 1535 ou 1536:

"Nam ha duvida que as navegações deste reyno de cem annos a esta parte: sam as mayores: mais maravilhosas: de mais altas e mais discretas conjeyturas que as de nenhuma outra gente do mundo. Os portugueses ousaram cometer o grande mar Océano. Entrarâa per elle sem nenhum receo. Descobriram novas ylhas / novas terras / novos mares / novos povos: e o q. mais ho: novo ceo: e novas estrellas".

"Ora manifesto he que estes descobrimentos de costas: ylhas: e terras firmes: nam se fizeram indo a acertar: mas partiam os nossos mareantes unuy ensinados e providos de estormentos e regras de astrologia e geometria: que sam as cousas de que os Cosmographos ham dãdar apercebidos" (2).

Justificam-se plenamente estas palavras de Pedro N:nnes porque, como mentor cosmográfico dos pilotos portuguêses, foi seu predecessor Mestre Jácome de Malhorca. Esste mandou-o vir da sua terra o Infante D. Henrique para ensinar as ciências da sua especialidade em escola então instituída ou em

(2). - Pedro Nunes, Obras de, publ. pela Academia das Ciências, Lisboa, 1940, vol. I, págs. 175 e 176. 
vias de se instituir em terra algarvia. O Infante tratava de fazer instruir os seus navegadores com as noções de cosmografia e de cartografia que lhes faltavam. O préstimo de Mestre Jácome de Malhorca não era sòmente o de desenhar e pintar mapas e de nêles representar as ilhas e terras que os caravelistas do Infante iam descobrindo. Como é óbvio, um primeiro e consciencioso delineamento cartográfico de qualquer litoral descoberto tinha de se fazer objetivamente e à medida que se divisavam e exploravam as diversas particularidades dêsse litoral, e não depois do regresso, quando já não era possível dissipar ou corrigir quaisquer dúvidas, erros ou missões.

As representações cartográficas da costa africana ḋ Atlântico ao sul das Canárias, tal como se mostram em vários mapas do século XV, constituem prova cabal de que os navegadores portuguêses da época haviam assimilado muitíssimo bem os ensinamentos de Mestre Jácome de Malhorca. Êste nunca fêz qualquer viagem ao litoral africano descoberto no tempo do Infante e isso significa que o seu trabalho no Algarve se limitava à instrução dos pilotos henriquinos.

Como se poderia explicar e justificar o primor da cartografia portuguêsa do século XV senão com a formatıra éscolar dos navegadores do Infante?!... Cosmógrafo e cartógrafo foi também Duarte Pacheco Pereira e êsse não se esqueceu de nos dizer quem fôra o mestre dos seus mestres. Escrito o Esmeraldo de situ orbis entre 1505 e 1508, ali se lê que o Infante

"mandou à Ilha de Malhorca por um mestre Iácume mestre de cartas de marear..., \& com muita: dálivas \& mercês ho ouve nestes Reynos ho qual as ensinou a fazer aquelles de que os que em nosso tempo vivem aprenderom" (3).

E' evidente que, neste passo do seu livro, alude Duarte $\mathrm{Pa}$ checo aos pilotos-cartógrafos henriquinos, com os quisis êle e os demais mareantes da sua geração haviam convivido e aprendido. Mestre Jácome de Malhorca fôra, pois, o instrutor dos navegadores do Infante e êstes é que foram os mestres dit geração subseqüente, uns lecionando em terra as noções teóricas da sua ciência e outros dirigindo a bordo a formação complementar dos praticantes.

Ao Infante se deve indubitàvelmente o primeiro surto evolutivo da ciência náutica portuguêsa. A navegação consciente .

(3) - Esmeraldo, cit., edição comemorativa do descobrimento da América, Lis' boa, 1892, liv. I, cap. 33, pág. 58 . 
no mar largo foi êle que a possibilitou com a escola em que fêz instruir as primeiras gerações de caravelistas dos descobrimentos. O Infante deixava o mundo em 1460 , mas a ciência cujo estudo êle promovera e impulsionara não mais deixaria de evoluir. Assim, subiria ela a um nível mais alto no tempo de D. João II, quando os nossos mareantes passaram a calcular as latitudes por meio de alturas meridianas do Sol. Da âplicação dêste método à navegação terão sido proponentes e mentores os "físicos e astrólogos" Mestre Rodrigo e Mestre José Vizinho, e talvez menos o primeiro que o segundo, posto que, eritão, para D. João II, era Mestre José Vizinho o cosmógrafo português de maior saber e idoneidade, a êle tendo confiado, ern 1484, o encargo excepcional de ir determinar as coordenadas geográficas de algumas terras de além mar.

Cientista de formação universitária, Mestre José Vizinho superava em conhecimentos cosmográficos todos os navegadores do seu tempo. Cometendo-lhe o encargo de determinar a situação geográfica de algumas terras ultramarinas, desejava D. João II ficar tão certo de tal situação quanto o permitissem os recursos científicos do seu douto cosmógrafo. Ora, entre êsses recursos - sabemos nós - incluia-se não só o do cálculo das latitudes por meio de alturas meridianas do Sol, mas também o da determinação da longitudes por meio de obervações dos eclipses solares e lunares, o que, aliás, não era estranho aos nossos navegadores, de quem Mestre José Vizinho se tornara mentor cosmográfico. São risíveis as longitudes que Cristóbal Colon diz ter obtido por observações de eclipses em duas ilhas do arquipélago antilhano (4), mas essas longitudes constituem boa prova de que êle vira praticar o método por algum dos seus mestres portuguêses, se não pelo próprio José Vizinho.

Assim, pois, cresceu a capacidade náutica dos navegadores portuguêses do século XV, e de tal modo em relação à dos navegadores espanhóis, que, em 1508, foi nomeado o florentino Américo Vespúcio para o cargo de pilôto-mor da Casa de Contratación de Sevilha e encarregado de ali ensinar "todos los pilotos"

"en lo que es necesario de saber en el ruadianle é estrolabio, para que junta la plática con la teórica se puedan aprovechar dello en los dichos viage:s cue hi ieron en las dichas partes [Indias Ocidentais], ć que sin lo saber no puedan ir en los dichos navios por pilotos. ni

(4). $\rightarrow$ Na ilha Espanhola (Haití), em 14 de setembro de 1494; e na ilha da Jamaica, em 29 de fevereiro de 1504. 
ganar soldadas por pilotage, ni los mercadores se puedan concertar con ellos para que sean pilotos, ni los maestros los puedan recibir en los navios sın que primero sean examinados..., é le sea dada por vos [Américo Vespúcio] carta de examinacion é aprobacion de como saben cada uno dellos lo susodicho" (5).

Era então a ciência náutica dos espanhóis bem rudiinentar, pois disso mesmo se queixa Fernando "o Católico" no documento donde transcrevemos a precedente passagem e cujo preâmbulo é do seguinte teor:

"Por cuanto á nuestra noticia es vellido, é por esperiencia habemos visto que por no ser los pilotes tan espertos como seria menester, ni tan estirutos en lo que deben saber que les baste para regir é gobernar los navios que navegan en los viages que se hacen por el mar Océano á las nuestras islas é tierra firme, que tenemos en la parte de las Indias, é por defecto dellos, é de no saber cómo se han de regir é goberilar, é te no tener fundamento para saber tomar por el cuadrante é estrolabio el altura, ni saber la cuenta de ello, lss han acaecido muchos yerros, é las gentes que debajo de su gobernacion navegan han pasado mucho peligro de que nuestro Señor ha seido deservido, é en nuestra hacienda, é de los mercadores que allá contratan, se tha revibido mucho daño é pérdida; é por remediar lo susodıcho, é porque es necesario que así para la richa navegacion, como para otras navegaciones, que con ayuda de nuestro Señor, esperamos mandar faser para descobrir otras tierras, es necesario qué haya personas mas espertas é mejor fundadas, é que sepan las cosas necesarias para las: tales navegaciones, é los que debajo dellos fucren puedan ir mas seguramente; es nuestra merced é voluntad, é mandamos que todos los pilotos de nuestros reinos é señorios, que agora son é serán de aquí adelanłe, que quisieren ir por pilotos en la dicha navegacion de las dichas islas é tierra firme, que tenemos a la parte do las Indias, é á otras partes en el mar Océano, sean instruidos é sepan lo que es necesario de saber en el cuadrante é estrolabio, para que junta la plática con la teórica se pıedan aprovechar dello en los dichos viages..." (b)

Tal era a insuficiência náutica dos navegadores espanhóis em 1508 e mesmo em anos posteriores. Eles navegavam para

\footnotetext{
(5): - Martin Fernnadez de Navarrete, Coleccion de los Viages $y$ Descubrimientos, edição de Buenos Aires, 1945, vol. III, pág. 299, doc. n.0 IX do "Apéndice de documentos pertenecientes a Américo Vespúcio".

(6). - Ibidem.
} 
as Canárias e foram algumas vêzes à Guiné, mas só por iniciativa e diligência de Cristóbal Colon se resolveram a percorrer com êle a distância que medeia entre as Canárias e as Antilhas. Eram navegadores de molde mediterrânico e, fazendo, como faziam, navegação costeira, não haviam adquirido conhecimento completo sôbre o condicionalismo pelágico e atmosférico do mar largo nem sôbre a utilização náutica do quadrante e do astrolábio.

E' bem evidente que os motivos imperiosos que levaram Fernando "o Católico" a instituir em Sevilha uma escola de navegação se haviam apresentado ao Infante D. Henrique por ocasião do povoamento das ilhas de Pôrto Santo e da Madeira, quando, lógica e necessàriamente, se estabelecia um tráfico marítimo regular com essas ilhas e se intentavam outros descobrimentos. Porque de duas, uma: ou os pilotos henriquinos aprenderam a fazer navegação de altura para saber encontrar as ilhas a que se dirigiam; ou se guiavam sòmente pela agulha e por grosseira estimação da distância percorrida é, então, iam ao acaso da sorte, como garotos de olhos vendados. no jôgo da "cabra cega".

Ora. no que concerne ao tráfico marítimo estabelecido com a Madeira e os Açores no tempo do Infante, não consta que um qualquer navio tivesse voltado a Portugal sem haver encontrado a ilha ou as ilhas aonde se destinava. Fiemo-nos, pois, no probo e douto Pedro Nunes e saibamos compreender que o referido tráfico não se fazia "indo a acertar". O transporte de povoadores e de mercadorias para a Madeira e Açores obrigava a despêsas de alto vulto e ninguém arriscaria o dinheiro assim envolvido sem a certeza de que os navios não iam ao acaso. Para que as suas viagens não fôssem baldadas, "partiam os nossos marcantes muy ensinados e providos. de estormentos e regras de astrologia e geometria" - ensinados, indubitàvelmente, em escola que o Infante D. Henrique: estabeleceu e manteve na então Vila de Lagos.

Poderão alguns historiógrafos continuar a dizer que "a: escola náutica daquela época era no mar, vivendo a hørdo dos: navios em íntima e plena promiscuidade com velhas e adestradas tripulações"-, mas êsses jamais terão considerado que quem não sabia cosmografia, cartografia e marinharia do mar largo - como era o caso dos pilotos espanhóis em 1508 e dos pilotos portuguêses um século antes - não podia ensinar essas ciências. 
No Algarve, pois, e em escola instituída e patrocinada pelo Infante de Sagres, é que se ensinaram as indispensáveis noções de cosmografia, cartografia e marinharia às primeiras gerações de caravelistas dos descobrimentos. Foram êsses navegadores que, em bordada da Madeira ou das Canárias para noroeste, descobriram a ilha de Santa Maria - à qual, logo depois, se seguiriam algumas outras dos Açores - e que, contornando semelhantemente os ventos proeiros de rordeste, quando regressavam das suas viagens africanas, adquiriram perfeito conhecimento do regime eólico do Atlântico Norțe.

Bom será advertir que não consideramos o astrolábio náutico um instrumento usado pelos navegadores portuguêses no tempo do Infante D. Henrique (7). O astrolábio teria sido adaptado ao uso dos nossos mareantes por volta de 1480 , quando o herdeiro de $\mathrm{D}$. Afonso $\mathrm{V}$, tendo em vista a intensificação do tráfico de permutas com o gentio da Costa do Ouro, ordenou os preparativos para a construção do castelo-feitoria de São Jorge da Mina. E' que, sanada a contenda de D. Afonso V com Isabel de Castela e Fernando de Aragão, e excluídos os espanhóis do tráfico da Guiné, chegara a hora de incrementar e abreviar o transporte de ouro da Mina para Lisboa e de continuar o descobrimento da costa africana para o sul do Cabo de Catarina, que era o limite alcançado pelos caravelistas de Fernão Gomes.

Certo é que os elementos essenciais para a feitura do "Regimento do estrolábio e do quadrante" impresso em 1509 - bem conhecido pela reprodução fac-simile a que anda ligado o nome venerando do Dr. Joaquim Bensaude - foram tirados do Almanach perpetuum do judeu salamantiro Abraham Zacuto. Mas, se consideramos que êste trabaltn de Zacuto foi elaborado entre 1473 e 1478 (8), torna-se evidente que a feitura do primeiro espécime manuscrito do referido Regimento é posterior ao último daqueles anos.

\footnotetext{
(7). - Diz o sr. Dr. Oliveira Boleo (Descobrimentos Marítimos e Exploraçōes Terrestres, Lisboa, 1955, pág. 69) que "as obras de Zurara se referem ao astrolábio como instrumento bem familiar nas nossas navegaçōes". Isto eqüivale a dizer que o uso do astrolábio a bordo dos navios portuguêses remanta ao tempo do Infante D. Henrique. Mas o instrumento a que alude Zurara nas suas obras é o astrolábio planisférico, usado pelos que se dedicavam $\longrightarrow$ como o próprio Zurara - à astrologia judiciária (cfr. Dr. Luciano Pereira da Silva, obras Completas, vol. II, Lisboa, 1945, págs. 250-251, passim) e não o astrolábio reduzido, a que, com tôda a propriedade, chamamos astrolábio náutico.
}

(8). - Cfr. Dr. Luciano Pereir ada Silva, ob. cit., vol. II, pág. 169. 
E' bem sabido que astrolábio e quadrante são instrumentos distintos, mas não será supérfluo dizer ou repetir que distintas eram também as suas utilizações. O primeiro era, na sua época, o instrumento considerado ideal para medir as alturas meridianas do Sol, pois dispensava a visão direta do astro e, tido em mão algum tempo antes do meio dia, permitia observar o aumento progressivo da altura até ao exato momento da culminação. O segundo era o mais apropriado para medir as alturas da estrêla Polar, dado que, com êle, se podia visar diretamente a estrêla até que o fio de prumo tivesse um momento de quietação na vertical e na coincidente divisão da escala graduada do instrumento. O astrolábio, com o seu Regimento, era utilizável em tôda parte; o quadrante só tinha serventia náutica nas regiões onde a Polar era visível, mas não ao longo nem ao largo do litoral do Gôlfo da Guiné, onde o brilho da estrêla não vence a opacidade vaporosa dos horizontes.

Os descobrimentos efetuados no tempo do Infante D. Henrique tiveram o seu limite na Serra Leoa e até êsse limite, em tôda a largura do oceano, podia bem medir-se a altura da Polar com o quadrante. A necessidade de obter as latitıdes por alturas meridianas do Sol nunca foi ressentida senão depois de descobertos os litorais africanos do citado Gôlfo. Assim se compreende e justifica a tardia utilização dêste método, sendo certo que a notícia mais antiga do seu emprêgo remonta a 1482, quando Diogo de Azambuja dêle se serviu para determinar a latitude de São Jorge da Mina (9).

Seremos, pois, fiéis à mais estrita verdade histórica dizendo que o quadrante e o astrolábio náutico caracterizam duas fases progressivas da ciência náutica portuguêsa do século XV. O quadrante, aliás, pode ser tido como símbolo da escola de cosmografia, cartografia e marinharia instituída e mantida pelo Infante D. Henrique em terra algarvia (10). De cosmografia e cartografia, porque os caravelistas do Infante faziam navegação de altura (11) e sabiam representar cartogràficamente a situação $\mathrm{e}$ os delineamentos costeiros das terra.s que iam descobrindo; de marinharia, porque em 1434, de-

\footnotetext{
(9). - Hist. da Col. Port. do Brasil, vol. II, Pôrto, 1923, pág. 373 e nota 83 inserta na mesma página:

(10). - Instituição de caráter privado, funcionando em ambiente restrito, não suscitava então mais referência do que qualquer das muitas escolas particulares onde, geralmente, se ensinavam as primeiras letras.

(11) . - Por bastante divulgadas, não citamos as palavras confirmativas do alemão Nicolau Lanckman de Valckestein e do português Diogo Gomes de Sintra.
} 
pois de, por espaço de "doze anros continuados" (12), ter sido explorada a região oriental do Atlântico compreendida entre as alturas do Cabo Bojador e dos Açores, sabiam os "criados do Iffante" que era possível descobrir a costa africana então desconhecida, indo por rota direta e contornando, no regresso, os ventos proeiros de nordeste. Disto temos boa prova no exemplo de Airas Tinoco, "hum moço da camara do Iffante". Dêle se ocupa Gomes Eanes de Zurara na sua Crônica dos feitos de Guiné (13), porque, atacados e mortos, pelos negros, o capitão, os "mareantes" e outra gente do navio em que servia, tomou a si o encargo de orientar a rota de regresso e "per dous meses continuados encaminhou a viagem daquelle navio". A prática de mar seria bem incipiente cm "tam pequeno moço", mas êle sabia que a rota de regresso a Portugal se fazia pelo largo, contornando o vento de nordeste, pois "em toldos aquelles dous meses nunca ouveram nhuma vista de terra".

Um fato devemos aqui salientar: dos que, em tal caravela, escaparam à sanha homicida dos negros - dois escudeiros feridos, um grumete, um moço da câmara do Infante, um moço guinéu e "outros dous moços assaz pequenos" - só Airas Tinoco soube resolver o problema da rota de regresso $\mathrm{E}$ não cabe pensar que êle já tivesse a experiência de uma viagem anterior, porque, com tal antecedente, não o consideraria Gomes Eanes de Zurara como inspirado ou "avisado per graça devinal" quando "o grumete em que elles (os outros sobreviventes) sua sperança tiinham, claramente confessou sua pouca sabedorya, dizendo como não sabya rotear nem trabalhar acerca dello em cousa que aproveitasse, soomente que se per outrem fosse encamynhado, que farya quanto podesse naquello que lhe mandassem".

Não fôra, pois, nessa viagem ou em outra anterior que Airas Tinoco aprendera o truque de contornar o vento proeiro de nordeste para vir da Guiné a Portugal. Êle valeı-se, simples e humanamente, das noções de marinharia ensinadas na escola náutica do Infante.

Este caso de Airas Tinoco sugere-nos uma outra consideração, e é a de que Gil Eanes só se teria disposto a ultrapassar o Cabo Bojador com a ciência e consciência de que podia

\footnotetext{
(12) . - Gomes Eanes de Zurara, Crônica dos feitos de Guiné, edição de Lisboa, 1949, cap. VIII, pág. 50; e João de Barros, Asla, edição de Llsboa, 1945, primeira década, liv. I, cap. II, págs. 15-16, e cap. IV, págs. 23 e 24.

(13). - Cap. LXXXVI, págs. 374 a 380 .
} 
voltar. Natural de Lagos e escudeiro do Infante, êle foi, certamente, um dos bons alunos da escola náutica lacohrigense.

Tudo isto se torna bem compreensível se consideramos que, para vencer os ventos de nordeste no regresso da costa africana de além Bojador, necessário teria sido dispor de navios próprios para bolinar. Mas além dêste requisito essencial, necessário também teria sido instruir os navegadores de que a maneira mais eficiente e menos fatigante de progredir para o norte, era navegar à bolina com o vento por estiburdo, persistindo nessa bordada até que outros ventos permitissem singrar na direção de Portugal e verificando a progressãr. em latitude pela altura da Polar. A/ Madeira constituia para êles uma escala de recurso e o conhecimento da altura dava-lhes a certeza de não errar a ilha quando ali tivessem de recomporse dos azares das viagens.

Não há dúvida de que, desde a segunda ou terceira década do século XIV até à época do povoamento da Madeira, se verificaram algumas expedições às Canárias por parte $d \in$ genoveses, portuguêses, castelhanos e franceses. Isso, porém, não implicava métodos inusitados de navegação, pois as $\mathrm{Ca}$ nárias situam-se em relação à costa de Africa como as Berlengas em relação à costa de Portugal (14).

Embora devido o primeiro descobrimento do grupo insular da Madeira a uma das expedições efetuadas às Canárias na primeira metade do século XIV, como é hoje geralmente admitido, ninguém se antecipou a João Gonçalves Z:arcs e a Tristão Vaz Teixeira na ocupação e povoamento de tais ilhas. Os primeiros descobridores do arquipélago não teriam deixado de avaliar a magnificência e a utilidade do seu achado, mas, se posteriormente tentarem ali voltar para promover a realização de quaisquer projetos, nunca souberam reencontrar o que buscavam. E' que os navios de vela não singram para uma ilha no mar largo como automotoras sôbre carris. Várias causas, tais como correntes, mau tempo, vento desfavorável, variabilidade ocasional e indeterminável de rumos e abatimentos, os fazem desviar pouco ou muito do caminho direto, o que, òbviamente, constitui incógnita irresolúvel para qualquer "argonauta" alheio à navegação de altura .

Não falta quem pense que ir de Lisboa aos Açores numa caravela era coisa muito fácil, bastando, para tanto, seguir ao rumo de oeste. Mas os que assim pensam não consideram a

(14). - Ou como as ilhas do Mediterrâneo em relação às costas que lhe são adjacentes. 
eventualidade corriqueira do vento impor um rumo divergente, como seria o caso quando, soprando durante alguns dias de oes-noroeste, por exemplo, não permitisse fazer melhor caminho que o de entre sudoeste e oes-sudoeste. Dir-se-á que, navegando assim o navio durante certo espaço de tempo. poderia depois lançar uma bordada para o norte até compensar o que derivara para o sul, mas nem tudo é como à primeira vista se afigura, porque o vento pode mudar de fôrça $e$ de direção em momento imprevisível. como pode acalmar, tornar-se mais ou menos favorável, ou perfeitamente prociro. E se a tais considerações se aduz a da computação incerta das distâncias percorridas, far-se-á idéia de como seria difícil encontrar os Açores sem os meios que permitissem determinar a latitude do navio e o que ela pudesse diferir da latitude das ilhas, cujo paralelo médio - digamos — constituia o caminho a que, após qualquer desvio, sempre se devia volver.

Para que os navios do século XIV não deixassem de encontrar os seus objetivos no mar largo, necessário thes era atingir as latitudes dêsses objetivos pelo lado mais favorável - leste ou oeste - e, então, navegar para êles sôbre os respectivos paralelos (15). Não há, porém, que ter dúvidas: êstes preceitos de marinharia nunca se praticaram antes da

(15). - Supérfluo será buscar apôio alheio para o que dizemos. Mas, assim mesmo, apraz-nos invocar o que sôbre o mesmo tema escreveu Fernando Colon, que, além de sapiente cosmógrafo, foi também proficiente miestre de pilotos e experimentado navegador. Ouçamo-lo:

"En la arte de la navegacion hay tres cosas principales que en él sirven, que son: Altura, carta y aguja. Por el altura se sabe, en cualquiera lugar en que el hombre está, así en la mar como en la tierra, qué altura tiene, esto es, qué tantos grados está apartado de la línea equinocial.

"La carta enseña el camino o rumbo por donde se ha de navegar de un lugar á otro de aquellos que en ella estan señalados, en los cuales lugares primero se tomó la altura, y conforme aquella se situaran $y$ señalaran en la carta.

"El aguja enseña los nombres destos caminos o vientos que la carta tiene, los cuales son sacados de un principio o punto cierto, y en lugar fijo que la misma aguja enseña de qué parte del horizonte viene cada uno de los dichos vientos... Pues digo asf, que si uno parte de veinte grados y va en demanda de una tierra que está en los mismos veinte grados, o más, o menos, que a éste, aunque el aguja, vientos, corrientes, o otra cosa, sabida o no sabida, lo aparten del camino que ha de llevar, que él, con el altura se puede emendar $y$ volver a su camino, hasta llegar al término o lugar donde va." (Colóquio sobre las graduaciones diferentes que las cartas de Indias tienen. Interlocutores: Fulgencio e Teodósio. Teodósio emite os conhecimentos náuticos do próprio Fernando Colon. Biblioteca de la Academia de la Historia. Coleccion Muñoz, tomo 44, folios 1 a 7 . In Historia del Almirante Don Cristóbal Colón por su híjo Don Hernando (versão castelhana de Manuel Serraño y Sanz), Ma. drí, 1932, vol. I, págs. CLVII-CLVIII do Proêmio). 
época do Infante D. Henrique. Éles foram concebidos por ocasião do povoamento da Madeira, como, de resto, podemos evidenciar de modo mais compreensível e concludente.

A posição geográfica do grupo insular da Madeira em vários mapas do século XIV não diverge muito da que realmente lhe corresponde. As ilhas de Pôrto Santo e da Madeira estavam, pois, desde a época do seu primeiro descobrimento, à mercê de quem as quisesse tomar e povoar, mas até ao fim da segunda década do século XV ninguém se fêz dono de tão úteis logradouros oceânicos. Entretanto dava-se o caso de dois reis portuguêses - D. Afonso IV e seu neto D. Fernanaio se atribuirem o senhorio das Canárias, tendo mesmo o primeiro dêsses monarcas reclamado, em 1345 , contra a donação que delas fizera o papa Clemente VI a D. Luís de La Cerda, o chamado "Principe de las islas Afortunadas".

Por que êste empênho em possuir as Canárias e nenhum em possuir o grupo da Madeira, que, no entanto, era bem mais aliciante pelo seu menor afastamento de Portugal, pela sua total carência de habitantes e pela pronta utilidade a que òbviamente se prestava?!... Para responder a esta interrog:ção não há senão duas alternativas: ou o primeiro descobrimento do grupo da Madeira data apenas do fim da segunda cécada do século XV e, então, a representação do mesmo grupo nos mapas do século precedente resulta de aditamentos posteriores; ou êsse primeiro descobrimento é fato acontecido na primeira metade do século XIV e, nesse caso, ninguém $\in$ fetivou a ocupação das ilhas antes da época do Infante D. Henrique por não ser ainda praticada a navegação de altura.

Essta segunda alternativa é, quanto a nós, a verdadeira. Mas, que assim não fôsse e que da outra se pudesse derronstrar a prevalência, um fato ressalta nítido, concreto c imutável: só a partir de 1420 se conceberam as regras de cosmografia e marinharia praticadas pelos navegadores henriquinos e êstes, como é óbvio, não as aprenderam a bordo dos navios mas em escola para o efeito instituída pelo Infante na sua vila de Lagos.

Ao Infante D. Henrique - como escreveu João de Barros (16) - não

"faleceram pensamentos de altas imprêsas e obra: de generoso ânimo". "Parte das quais se viram quaricło se achou em África, principalmente na tomada de Ceita...,

(16)̣. - Asia, edição citada, déc. I, liv. I, cap. XIV, pág. 66. 
e assi nesta imprêsa tam nova de descobrir a que lé o seu tempo estava encoberto.

"Em que não sòmente encaminhou as cousas ao iom sucedimento delas, mas ainda teve nêle muitil industria e prudência pera conseguirem próspero fim. Por que para este descobrimento, mandou vir da ilha de Malhorca um Mestre Jácome, homem mui douto na arte de navegar, que fazia cartas e instrumentos, o qual !he custou muito polo trazer a êste reino, pera ensinar sua cî́ncia aos oficiais portugueses daquele mister."

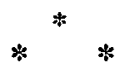

As considerações que a seguir se apresentam são as que formulei no Congresso em refôrço e defesa do meu precedente trabalho. O resumo publicado no livro do mesmo Congresso não era para tomar-se como manual informativo de tudo - que constituia o recheio da minha tese, e esta foi parar às mãos de um relator para quem não houve no tempo do Infante D. Henrique senão "uma técnica de marinharia lenta e empiricamente conquistada em convívio com o mar pelos navegadores de Lagos e Lisboa" (17).

Sentia-me, portanto, obrigado a corroborar o mais que pudesse a tese em referência e, assim, comecei por dizer que,

"embora conhecida a existência do arquipélago da Madeira desde a primeira metade do sézulo XIV, ccmo afirmam muitos historiógrafos, nunca ninguèn, até à época do Infante, se mostrou interessado na sua pusse. Isto é, a existência do arquipélago da Madeira seria sabida de genoveses, maiorquinos, catalães, castelnanos, portıguêses e talvez doutros, mas as ilhas estiveram sem dono até à ocasião do seu achamento por João Gonçalves Zarno.

"Coisa idêntica se pode dizer dos Açores. se: admitimos, como muitos querem, um seu primeiro descobrimento em época indeterminada, mas cêrca de unı século antes dos portuguêses ali levarem a sua prescnça e a sua soberania.

"Evidentemente que o fato dos dois arquipélagos não terem tido dono até à época do Infante tem uma explica-

(17). - o relator a que me refiro é o Prof. Dr. Luís Mendonça de Albuquerque, autor de um trabalho publicado no tomo n. 41 , de janeiro-março de 1960, desta "Revista de História", sob o título: "O problema das latitưdes na náutica portuguêsa do século XV".

Apresentou o mesmo ilustre Professor uma comunicação ao Congresso sôbre "A determinaçāo de latitudes por alturas meridianas de estrêlas na náutica dos Descobrimentos". Esta comunicação foi distríbuída à mesma 2a. Subsecção da 1a. Seç̧ão e, discutida um dia antes da minha, não passou sem alguns justos reparos de minha parte. 
ção e eu, francamente, não encontro outra qụe não seja a de nunca haver sido praticada a navegação de alıura até à ocasião do povoamento das ilhas de Pôcto Sianto e da Madeira.

"Vejamos que se as ilhas representadas on alguns mapas do século XIV, em frente da costa de $P_{0}$;:tugal, assinalam verdadeiramente o primeiro descobritrento dos Açores - o que eu, aliás, não aceito -, elas cunstituem boa prova de que os seus primeiros descobildores nada sabiam de alturas e latitudes. As ilhas foram representadas em fieira paralela à costa de Portugal e. portanto, muito diferentemente da maneira como estão dispostas as do arquipélago açoreano, e quanto à distânciz a que as situaram do litoral português, ela orça por vêrca de metade daquela a que realmente se situam as veidacieinas.

"Para mim, a representação do grupo insular da $\mathrm{Ma}$ deira nos mesmos mapas assinala, de fato, um desccbrimento realizado na primeira metade do sécul' . IIV. Não o juro porque, apesar disso ser considerado hoje. pir alguns historiadores, um caso provado e assent,e, outrus há que dizem ter sido interpolado em épocas posteriores o documento comprovante, o qual, como é sabido, é constituido pelo "Libro del conocimiento de todos los Reynos y Tierras y Señorios", escrito em meados do século XIV por um frade espanhol anônimo.

"Considero, portanto, representações de fantasia as ilhas figuradas nos tais mapas ao longo e ao largo da costa de Portugal. E se tomo como verídico um pririeiro descobrimento do grupo da Madeira na primei a nıctade do século XIV, isso é principalmente para demonstrar, de tôdas as maneiras, que o seu povoamento $s \leq$ foi possivel quando o Infante estabeleceu no Algarve uma escola de Cartografia, Cosmografia e Marinharia do mar largo para formação dos seus pilotos.

"Antes da época do Infante - e aqui não há que ter em conta o caso das Canárias, que se situam em relação à costa africana como, por exemplo, as Balearts en relação à costa mediterrânica da Espanha -- nenhumas outras ilhas verdadeiras, além, talvez, das do grupo madeirense, haviam sido descobertas ao largo dos litorais europeu e africano e isso, evidentemente, porque os marinheiros dêsse tempo não possuiam as habilitações necessárias para fazerem navegação consciente longe das rotas costeiras. Oitenta anos depois de se ter começado a povoar as ilhas de Pôrto Santo e da Madeira ainda, com os espanhóis, aconteciam casos como os que vamos fazer ouvir, recorrendo, para tanto e em primeiro lugar, ao Diário da primeira viagem espanhola de Cristólal Cclon às Antilhas, onde, na parte referente ao dia 15 de 1evereiro de 1493, se lê: 
"Viernes 15 de Hebrero - Ayer, despues deI sol puesto, comenzó á mostrarse claro el cielo de la banda del Oueste, y mostraba que queria de hácia allí ventar; dió la boneta á la vela mayor; todavía era la mar altísima, aunque iba algo bajándose; anduvo al Lesnorcieste 4 millas por hora, $y$ en trece horas de noche iueron ia leguas. Despues del sol salido vieron tierra; pareríales por proa al Lesnordeste; algunos decían que era la Isla de la Madera; otros, que era la Roca de Sintra, en Portugal, junto á Lisboa. Saltó luego el viento por proa al Lesnordeste, y la mar venía muy alta del Oueste; habria de la. carabela á la tierra 5 leguas. El Almirante, por su navegacion, sehallaba estar con las Islas de los Azores, y creía que aquella era una dellas; los pilotos y marineros se hallaban ya con tierra de Castilla."

"Episódio idêntico se verifica no regresso da segunda. viagem e nas cercanias do Cabo de São Vícente. Eis como. Fernando Colon relata o caso:

"Siguiendo su camino, el miércoles 8 de Junio, sendo. todos los pilotos como ciegos y perdidos, llyegaron a la vista de Odmira, que está entre Lisboa y el cabo de San Vicente, habiendo pasado muchos días que todos los oiros pilotos se acercaban siempre a tierra, excepto el Almirante que la noche anterior hizo amainar las velas por miedo al peligro de tierra, diciendo que hacía esto porque se hallaban cerca del cabo de San Vicente. De 10 cual se reían todos, afirmando algunos que estaìan en el canal de Flandes $y$ otros que cerca de Inglaterra; $y$ los que menos se equivocaban decían hallarse en Galicia...".

"Assim não será lícito pretender que foi $\mathrm{ccm}$ navegadores como êstes que os caravelistas henriquinos aprenderam a demandar com segurança e acêrio quaisquer objetivos no mar largo. Aprenderam sim, mas em escola para o efeito instituída e mantida pelo Infante na então vila de Lagos.

"Disse eu na minha comunicação que o quadrante pode ser tido como símbolo da escola de cosmogiafia, cartografia e marinharia instituida e mantida pelo Infante $D$. Henrique em terra algarvia. Ora até hoje ninguém ronseguiu provar que o astrolábio reduzido tivesse sido usa-. do pelos navegadores portuguêses no teinpo do Infante. Aliás, os descobrimentos efetuados em vida de D. Henri-. que não ultrapassaram a Serra Leoa e até aí ìa o quadrante instrumento suficiente para as navegaçōes dos seus caravelistas, pois o astro usado para as alturas, a bordo, era sòmente a Polar. Esta estrêla podia visır se direta- 
mente com o quadrante e, assim que se obtinha um momento de quietude do fio de prumo na verticai, premiase êste fio contra a escala do instrumento e lia-se a altura do astro na divisão coincidente. O metodı lão facultava no mar uma grande exatidão, mas a neédịa dııma qualquer série de alturas consecutivas jodia ser considerada como expressão da verdade desejada, e, assim, nunca os navegadores portuguêses da época da Infinte deixaram de encontrar as ilhas para onde transportivam povoadores e mercadorias.

"Há quem afirme que êsses navegadores nunca iveram conhecimento do movimento diurno al Fular. 'L'wna-, vam-na, segundo se diz, como astro fixo no polo coleste e por isso cometiam grandes erros, na determin:ação das latitudes. Com isto diz-se também que o prirne:ro Ri-gimento conhecido da Polar data de 1509 , e que nuesmo admitindo ter o mesmo circulado manuscrito durante os vinte e cinco anos precedentes, êle nunca teria chegado a ser usado pelos caravelistas do Infante. Dêste riodo. dizse ainda, não há que atribuir grande exatidão às navegações dêsses caravelistas, pois os erros por êles cometidos nas alturas da Polar podiam atingir ou mesn:o ultrapassar a cifra de quatro graus, visto como então a distância polar da estrêla era de cêrca de três e meio graus.

"Mas, pergunto eu, se assim fôsse ousaria alğuém confiar-lhes o transporte de povoadores e mercadorias para as ilhas da Madeira e dos Açores?!... Vejamos que em tais circunstâncias e nos meses em que as noites atingem ou ultrapassam a duração de duze bo ‘s, poderia ser de cêrca de sete graus a diferença qu' se obteria nas alturas da Polar quando estas fôssem tomadas nos momentos em que a estrêla cortasse os lados inferior e superior do meridiano. E' evidente que, confrontado com tamanha diferença, qualquer dos referidos navegadcres seria levado a pensar que havia errado a mediç̃̃o de tima das alturas ou das duas, por isso que, no seu intender, a altura da estrêla não devia variar senão cọn a deslocação do navio em latitude. Uma grande confusão não deixaria, certamente, de se produzir no seu espírito posto que, considerando a estrêla fixa no poio ceieste, não tinha outro meio de dissipar as suas dúvıdas e incertezas - e o resultado conseqüente de tal estado de coisas seria, naturalmente, o de deitar o quadrante ao mar e voltar para casa! Mas, pergunto ainda, não teria êsse navegador discernimento bastante para n'vtai que as diferenças das alturas da estrêla tomadas a horas diferentes da noite e num mesmo lugar eram devidas ao movimento diurno do astro?... não percebəria êle que 
tomando alturas de outra estrêla da mesma cinstelação o caso se repetia da mesma forma e ainda em maiores proporções?... Não veria êle que, num mesmo lıgar, a cada posição diferente da Ursa Menor, no círcuı em que aparentemente se move, correspondia urma altura diferente da Polar?... E depois, como deman.lar : Ima ilha qualquer com alturas que ao anoitecer podian ser de $\rightarrow$ supunhamos - trinta graus e ao amanhecer de trinta e sete?... Sim, porque a altura certa do polo só por acaso seria tomada em tais circunstâncias e por tal navegador, mas dessa altura, como das outras, náci saberia êle reconhecer a exatidão e a utilidade!

"De resto, não era com a altura mas com a latitude que se demandavam as ilhas conhecidas do mar largo. E' bem de ver que, se assim não fôsse, seria necessário possuir tabelas que dessem a altura da Polar em cada grupo de ilhas para as várias posiçñes da Ursa Menor no firmamento. Mas não seria isso m'tito mais complicado que um simples Regimento onde se biscassem as correções para aplicar à altura e obter a latitude?...

"Eu estou certo de que o primeiro Regimente da Polar, embora desconhecido, foi elaborado por ocasião do povoamento das ilhas de Pôrto Santo e da Madeira, pois só assim os navios as podiam demandar com scgurança e acêrto. Esse Regimento foi, com cesteza, ensinado aos pilotos henriquinos juntamente coin as regras de marinharia a tal navegação adeqüadas, pois as ilhas demandavam-se em latitude e não em rumo direto, como geralmente se pensa.

" $E$ onde se ensinaram êsses truques náuticus aos navegadores do Infante?... Tudo o que acabo de expor me corrobora a certeza de que tais truques lhe foram ensinados em Escola instituída pelo Infante e'n ter:a algarvia, e não a bordo dos navios, nos quais então ninguém se encontrava que dêles fôsse sabedo:".

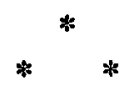

Vejamos agora as objeções que me foram opostas pelo primeiro dos meus dois referidos contraditores. Ao ilustre relator ouvi eu as seguintes:

a). - Não se conhece nenhum documento quatrocentista que direta ou indiretamente se refira a uma qualquer escola náutica criada pelo Infante D. Hen:ique. As palavras por mim citadas de Pedro Nunes e João de Barros nada provam. São testemunhos iardios em relação à época do Infante. 
b). - Os pilotos portuguêses do século $X V$ não eram cartógrafos. Anotavam em seus livros a exterisão $\epsilon$ os rumos das costas que iam descobrindo e por êsses apontamentos se acrescentavam depois nos mapas os novos trechos costeiros descobertos.

c). - Os pilotos henriquinos não se serviran de 'nétodos de navegação diferentes dos do Mediterıâneo no tempo do povoameritu dos arquipélagos da Madeira e dos Açores. No Mediterrâneo há espaços tão vastos como os que medeiam entre Portugal e a Madeira ? entre Portugal e os Açores, e isso não consti suia impedimento a que os navegadores dessa região encontra - sem as ilhas e os portos aonde se dirigiam.

d). - Não se prova que Diogo de Azambuja tivesse observado alturas meridianas do Sol em Sáo Jurge da Mina no ano de 1482. A fonte primária cie tal informação é o livro de Teles da Silva, De rebus gestis Jo-t hanni II, publicado em Lisboa, no ano de 1589.

e). - Ainda no fim do século XV os ravegadores portuguêses cometiam grandes erros na determinação das latitudes. Os mapas dessa época divergem tiduos na localização latitudinal do Cabo da Boa Esperança.

f). - Nas passagens citadas por mim do Diário da primeira viagem de Colon às Antilhas e do livro de Fernando Colon não estão em causa os pilotos mas sim os marinheiros e outras pessoas das equipagens

g). - O que se conhece do Diário da primeira viagem de Colon às Antilhas é um extrato feito por Frei Bartolomeu de las Casas e, assim, nenhuma das suas passagens pode ser invocada sem reservas. A parte lida por mim não constitui testificação aceitável da impreparação dos navegantes espanhóis para a marinharia do mar largo.

Não me recordo de que nenhuma outra objeção me tenha sido oposta pelo douto relator em referência. Tratarei, pois, de responder o mais brevemente possível a tudo o que consta do rol precedente.

Não se conhecem, de fato, nenhuns documentos quatrocentistas que se refiram direta ou indiretamente a uma qualquer escola náutica criada pelo Infante, mas ninguém pode afirmar que êles não tenham existido e perdurado até ao tempo de João de Barros e Pedro Nunes. Não desapareceram os mapas portuguêses da época? Não desapareceram a Casa da fndia e o seu valioso arquivo em 1755 , a quando do terremoto que destruiu a cidade de Lisboa? Não era a Casa da fndia a sucessora: do pri- 
meiro entreposto português do tráfico da Guiné estabelecido em Lagos pelo Infante D. Henrique e ainda hoje citado com a designação, que então lhe davam, de "Almazem da Guiné"? Não foi João de Barros feitor da Casa da fndia? Não tinha Pedro Nunes acesso ao arquivo da mesma Casa como cosmógrafo mor e examinador de pilotos? E' porventura lícito pretender, hoje, que homens como João de Barros e Pedro Nunes se refiram à preparação escolar dos pilotos henriquinos sem base em quaisquer notícias pertinentes provindas da época do Infante, a qual, de resto, para êles, era air,da bem recente? Para saber que existiram mapas portuguêses quatrocentistas nada mais seria necessário que conhecer as cópias estrangeiras que dêles se fizeram e que ainda hoje perduram. E, anàlogamente, para se ter a certeza de que existiu uma escola náutica em Lagos no tempo do Infante basta-nos saber que a navegação por alturas só foi iniciada no fim da segunda década do século XV com o povoamento das ilhas de Pôrto Santo e da Madeira. Para náuticos é isto uma verdade indiscutível, e não sou eu o primeiro a dizê-lo. Fontoura da Costa, ao referir-se "à poèticamente chamada Escola de Sagres", comentava:

"Como admitir que tão elementar ensino tôsse ministrado em Terça Nabal onde não havia povoaçãn. ou mesmo, mais tarde, na Vila do Infante, longe da Łase lagoense? Ensinou-se sim, mas em Lagos" ( $\mathrm{i} \%$.

E também doutro náutico, oficial da Marinha Militar Portuguêsa, o comandante José Moreira Campos, são as seguintes palavras:

"não podemos deixar de considerar que a emprêsa henriquina dos descobrimentos colheu todos os informes, nacionais e estrangeiros, contratou mestres para ensinar e preparar futuros marinheiros para descobrirem mais além" (19).

"O sábio mestre de navegação da Escola Naval comandante Fontoura da Costa - não podia conę ber que se fizessem viagens de povoamento e comércio entre Lisboa e Açores, sem se tomarem alturas do polo. E se alguém, na sua fantasia, entender que o contrário é coisa viável, ainda pode experimentar, hoje, meiendo-se num barco à vela, só com uma agulha pur meihor que seja. E no fim nos dirá o que lhe aconteceu" (20).

\footnotetext{
(18). - A Marinharia dos Déscobrimentos, Lisboa, 1939, págs. 11-12.

(19). - O Infante D. Henrique e os Descobrimentos Portuguêses, Lisboa, 1937, pág. 111.

(20). - Ibidem, págs. 115-116.
} 
Para náuticos, pois, é bem evidente o fato do Infante $D$. Henrique ter criado e mantido uma escola de navegação em terra algarvia. As viagens de povoamento e comércio para a Madeira e Açores são disso prova segura porque não só com documentos escritos se atesta a veracidade de um fato histórico.

*

Sôbre o ensino da cartografia aos pilotos henriquinos há o seguinte a ponderar. Quem sabia notar a extensão duma costa e os rumos a que corria, com seus cabos e rios, suas baías, montanhas, ilhas e outras conhecenças, seus recifes e baixios, também saberia decerto acrescentar e marcar tudo isso na carta de marear que levava consigo. Não havia nisto maior dificuldade do que naquilo.

Por bem extraordinário capricho da sorte não chegou até nós nenhuma carta de de marear portuguêsa do temṛo do Infante, mas não há que duvidar de que aos pilotos henriquinos se devem tôdas as primeiras representações cartográficas das costas que descobriram. E vejamos: que saberíamos nós hoje das aptidões cartográficas de Cristóbal Colo e de seu irmão Bartolemeu se não se tivessem passado para o serviço de Castela? Temos notícia de um pilôto-cartógrafo do temro de $\mathbf{D}$. João II e êsse, embora conhecido como grande navegador e descobridor, pois trata-se de Bartolomeu Dias, quase nunca é citado como autor da primeira representação cartográfica do longo trecho de costa africana que descobriu! E como sabemos nós hoje êste fato? Por uma nota do punho de Cristóbal Colon, ou do citado seu irmão, na margem de umá das páginas do exemplar da Historia rerum ubique gestarum, de Enéas Sílvio Piccolomini (Pio II), que pertenceu ao primeiro; por nada mais!

Como teríamos jamais sabido que era pilôto-cartógrafo o famigerado João Dias de Solis se êle não se tivesse homiziado em terras de Castela por crime de uxoricídio? E não eram pilotos-cartógrafos o espanhol Juan de la Cosa e os vários outros que trabalharam na Casa de Contratación de Sevilha nos primeíros tempos desta instituição? Ainda hoje se conserva na Biblioteca Real de Turim um mapa de 1522 assinado por: "Nuño Garcia de Toreño, piloto y maestro de cartas de navegar" (21).

(21). - Cfr. Armando Cortesão, Cartografia e cartógrafos portuguêses dos sé* culos XV e XVI, Lisboa, 1935, vol. I, pag. 284, nota 2. 
Dir-se-á que tudo isto é tardio em relação à época do Infante, mas o que cumpre reconhecer é que os homens citados se integram numa seqüência tradicional de pilotos-cartógrafos iniciada com os primeiros descobrimentos portuguêses. Tão fortemente se enraizou em Espanha a tradição da dualidade profissional dos pilotos-cartógrafos da época dos descobrimentos, que o cronista Antônio de Herrera, ao referir-se aos cartógrafos portuguêses - pai e filho - Pedro Reinel e Jorge Reinel, lhes chama "pilotos portugueses dé mucha fama" (22).

Justos em percepção e razoamento são os seguintes comentários do ilustre geógrafo e historiador inglês E. G. Raveinstein:

\begin{abstract}
"Não há dúvida que os primeiros aaveg'ddores cortuguêses trouxeram excelentes cartas das suas viağens. Colombo, que viu as cartas preparadas por Hartolcmeu Dias, fala delas como desenhando e descrevendo, légua a légua, o caminho seguido pelo explorador. Mas nem uma destas cartas originais sobreviveu, e se nác frossem as cópias delas feitas por italianos e outros, o nosso conhecimento destas primeiras explorações seria menos perfeito do que atualmente é" (23).
\end{abstract}

*

Para se discutir com acêrto o problema das habilitações náuticas dos navegadores henriquinos há que ter em mente a amplidão do Atlântico e a pequenez dos grupos insulares nêle dispersos, tais os da Madeira è dos Açores. Tendo isto em mente não custará muito a compreender que, para encontrar a costa do continente europeu vindo de qualquer dos citados grupos insulares, poderá bastar uma simples agulha, mas que, para fazer o inverso, outros recursos serão necessários, pois, no primeiro caso, haverá um longuíssimo litoral aonde se irá bater, enquanto que, no segundo, se pode ultrapassar o objetivo demandado sem disso se ter percepção.

O Mediterrâneo era para os seus navegadores cnmo que uma grande praça pública rodeada de casario e ornada de quiosques e obeliscos. Ora numa praça pública, por muito grande que seja, ninguém deixa de encontrar o que queira, porque ela só tem aberturas para as ruas que lhe dão acesso, e as edificações que a rodeiam constituem pontos de referên-

(22). - Historia General de los Hechos de los Castellanos en las Islas y Tierra Firme del Mar océano, ediçāo de la Academia de la Historia, tomo VI, Madrí, 1947, déc. III, liv. IV, cap. XIII, pág. 432.

(23). - Apua A. Cortesão, ob. cit., pág. 135. 
cia e orientação para os quiosques e obeliscos que lhes ficam fronteiros. Muito diferente, porém, será a imagem que se possa fazer da vastidão oceânica, onde, para demandar ụma ilha, não há outros pontos de referência senão os do céu. Se a êstes não sabe o mareante recorrer, a sua navegação é uma aventura, exatamente como a do sapateiro que se meteu a velejar para a Madeira e voltou com a notícia de que tôdas as ilhas do arquipélago se haviam afundado.

Pretender que os métodos náuticos dos pilotos henriquinos não diferiam dos que se praticavam no Mediterrâneo é um êrro só admissível em quem não tenha da navegação à vela a mais pequena noção. Fernando Colon, que foi professor e examinador de pilotos, explicava:

"Pues digo así, que si uno parte de veinte grados y va en demanda de una tierra que está en los mismos veinte grados, o más, o menos, que a éste. aunque el aguja, vientos, corrientes, o otra cosa sabida o no sabida, lo aparten del camino que ha de llevar, que él, con el altura se puede emendar â volver a su camino, hasta llegar al término o lugar donde va."

Assim, pois, se demandavam e encontravam as ilhas do Atlântico, e Fernando Colon não foi o inventor da navegação por alturas. Esta começou a praticar-se no fim da segunda década do século XV com o achado do grupo insular da Madeira e com o povoamento das suas duas ilhas principais. Disso não há que ter dúvidas.

Para saber como se navegava no Mediterrâneo há que recorrer, não a conjecturas fantasistas próprias ou alheias, mas ao testemunho de quem disso tinha experiência. A êsse respeito escreveu Cristóbal Colon:

"Los navegantes y otras gentes que tractan por la mar, tienen syempre mayor conoscimiento de las partidas particulares del mundo donde usan $y$ fazen sus contractaciones más continuo, y por esto cada unc destos sabe mejor de lo que vee cada dia, que no lo otro que viene de años ha años; $y$ así reszibimos cor delectazion la relazión quellos mesmos nos lazen ve lo que vieron" y collejieron, como cierto allegamos más giande enseñanza de aquello que deprendemos por nuestra espirenzia.

"Los que andan continuo de Cádiz a Nápoles, ya saben cuándo pasan por la costa de Catalunia, segund la razón, el viento que han de hallar en ella, y asymesmo 
cuáando pasan por el golfo de Narbona. Estos que han de yr de Cádiz a Nápoles, si es tiempo de yıvierno. van a vista de cabo de Creo, en Catalunia, por el golfo de Narbona: entonzes viento muy rezio y las vezes, las naos conviene le obedescan y corran por fuerza hasti. Berviaria, y por esto van más al cabo Creo, por sostener riás la bolina y cobrar las Pomegas de Marsella o las ysias de Hires, y despues jamás se desabarcan de la costa hasta llegar donde quier. Si de Cádiz ovieren de yr a Nápoles, en tiempo de verano, navegan por la costa de Berveria hrasta Cerdeña, ansy como está dicho de la otra costa lie la tramontana. Para estas navegaziones hay hombres señalados, que se han dado tanto a ello, que conosen iodos estos caminos y que temporales pueden esp yrat, segúnd la sazón del año en que fueren. Vulgarmente, a estos tales llamamos pylotos, que es tanto como en la ticrra adalid; que bien que uno sepa muy bien el camino daquí a Fuenterrabia para llevar una hueste, no lo sabe daquí a Lisbona. Esto mismo acaesze en la mar, que unos son pylotos de Flandes y otros de Levante, cada uno di la tierra donde va" (24).

Aí fica, pois, explicada a diferença que havia entre os pilotos portuguêses dos descobrimentos e os pilotos do Mediterrâneo. De notar é também que os pilotos das rotas do levante mediterrâneo não serviam para as rotas da Flandres, certo, como é, que para umas e outras se carecia de prática continuada. Não iria fazer papel de aprendiz numa região quem durante vários anos se havia afeito à navegação duma outra.

Passando agora ao que escrevi sôbre a observação de alturas meridianas do Sol em São Jorge da Mina, no ano de 1482, por Diogo de Azambuja, não deixarei de dizer que, com provas ou sem provas, o caso é mais de crer que de negar. Mas, ainda que destituído de valor histórico por falta de comprovação documental, êle em nada afeta a essência da minha tese. Com esta advertência preliminar não iludo a resposta que devo ao meu contraditor. Eu disse e sustento que a determinação das latitudes por alturas meridianas do Sol começou a ser praticada pelos navegadores portuguêses num dos primeiros anos do reinado de D. João II. Em abôno desta verdade invoco o fato de Cristóbal Colon haver observado

(24). - De uma carta escrita por Cristóbal Colon aos Reis Católicos em 6 de fevereiro de 1502. Publicada na Raccolta di Documenti e studi, Parte I, vol. II, Roma, 1892, págs. 161 a 163. 
alturas meridianas do Sol a quando das suas viagens à Guiné, ou seja em época compreendida entre a primeira quadra de 1482 e a terceira de 1485, porque em agôsto dêste último ano transferiu-se o mesmo Colon de Portugal para Espanha e o castelo-feitoria de São Jorge da Mina, onde êle diz haver estado, foi começado a construir no princípio de 1482 .

Mas eis outro bom argumento para apoiar o que digo; na Oração de Obediência de D. João II ao Papa Inocêncio VIII, lida na côrte pontíficia em 11 de dezembro de 1485 pelo Dr. Vasco Fernandes de Lucena, testifica aquêle Rei que, ao atingirem os portuguêses as proximidades do Promontório Prasso, haviam sido

"explorados os rios, praias e todos os portos que desde Lisboa, numa extensão de mais de 45 centenas de milhares de passos, estão enumerados com exatíssima observação do mar, das terras e dos astros" (25).

Ora a região afro-atlântica do hemisfério austral então tida como vizinha do referido Promontório foi atingida por Diogo Cão na sua viagem de 1482-1484 e se, como dá a entender o documento citado, êle fêz observações astronômicas para determinar a latitude de vários pontos da costa que descobriu, isso quer dizer que do seu equipamento náuticc faziam parte um ou mais astrolábios e o respectivo regimento. Assim, pois, julgo bem estar com a verdade dizenúo que o cálculo das latitudes por alturas meridianas do Sol a bordo * dos navios portuguêses dos descobrimentos remonta. pelo menos, ao ano de 1482 .

Posta a questão em tal pé, e sabendo-se que Diogo Cão passou pela Mina em 1482, por ser "logar onde se podia prover de alguma necessidade" (26), nãa se deve descartar a possibilidade de que ali, com êle, tivesse Diogo de Azambuja experimentado o método de "pesar" o Sol ao meio dia para saber a "ladeza" do "logar". O caso, se real, poderia ter sido mencionado pelo mesmo Diogo de Azambuja em relatório subseqüente elaborado para informação de D. João II, $€$ êsse relatório poderia ter perdurado até à época em que Teles da Silva escreveu o seu De rebus gestis Johanni II, pois êste livro data de 1689 e o arquivo dos Paços da Ribeira só desapa-

(25). - Apud Dr. Damiāo Peres, História dos Descobrimentas Portuguêses, Pôrto, 1943, pág. 194.

(26). 一 João de Barros, Asia, đéc. I, liv. III, cap. III, citado por Damião Peres, ibldem, pág. 189. 
receu em 1755, a quando do terremoto que destruin a cidade de Lisboa.

O que eu não aceito como bom é que Mestre José Vizinho tivesse sido mandądo à Guiné em fins de 1484 ou no comêço de 1485 para "experimentar pràticamente o "regimento do sol" e "pôr à prova a sua exatidão em lugares onde o sol culminava a norte do zenite" (27). Tenho para mim que a ida de Vizinho ao ultramar foi motivada por necessidades bem diferentes, pois que do simples cálculo das latitudes por alturas meridianas do Sol em qualquer lugar da Guiné podia ser encarregado qualquer dos pilotos que para lá faziam viagens, tal o competente Pero de Alenquer, por exemplo. Em tal época, de resto, o Sol só culminava a norte do zenite de São Jorge da Mina a partir da última semana de março e, segundo Cristóbal Colon (28), foi em 11 de março de 1485 que Mestre José Vizinho determinou a latitude de uma das ilhas dos fdolos, situadas, aliás, em paralelo mais setentrional. Nenhuns outros elementos se conhecem pelos quais se possa concluir ou provar que foi depois de tal data que o mesmo Vizinho esteve - se esteve - em São Jorg da Mina, e é muito possível que a sua paragem numa das citadas ilhas dos fdolos tivesse sido feita a quando da viagem de regresso.

Aludi anteriormente ao pilôto Pero de Alenquer e antepus ao seu nome o adjetivo "competente". Veremos agora as razões em que me estribo para tanto. E' que Pero de Alenquer foi companheiro de Bartolomeu Dias na viagem de ciescobrimento do Cabo da Boa Esperança e a êle, tanto como aos capitães e outros pilotos da expedição, se deve a primeira latitude calculada para o mesmo Cabo. Teriam êsses homens errado em muito a referida latitude, como, com base numa das notas de Colon e em vários mapas de épocca pouco posterior, se tem afirmado? $\mathrm{A}$ isto respondo imediatamente com um não categórico. A desigualdade latitudinal do Cabo da Boa Esperança nos referidos mapas, todos êles cópias de cópias, é ùnicamente atribuível a quem os desenhou. A carta original apresentada por Bartolomeu Dias a D. João II não é corhecida e essa, não tenhamos dúvidas, situava o Cabo em latitude

\footnotetext{
(27). - Vide Revista de História, n.o 41, de janeiro-março de 1960, págs. 33-34. (28): - Vide nota de seu punho inserta na margem de uma das páginas do exemplar, que lhe pertenceu, da Historia rerum ubique gestarum, de Eneas Silvio Piccolomini (Pio II). Publicada na Raccolta di Docomenti e Studi, vol. cit., pág. 369 , sob o n.० 860.
} 
muito próxima da verdadeira. Para o provar invoco $u m$ fato concreto e não inédito, um fato que em geral se ignora nas críticas que se fazem a trabalhos dêste gênero.

No decurso da sua primeira viagem à fndia, Vasco da Gama entrou na baía de Santa Helena e ali, com Pero de Alenquer e os outros pilotos, foi a terra para determinar a latitude dêsse ponto da costa ocidental africana (29). Com isso ficou sabendo a distância a que estava do Cabo, e essa distância, segundo o parecer então emitido por Pero de Alenyuer, não era de mais de trinta léguas (30) . Ora, Pero de Alenquer não conhecia o trecho costeiro em que se enquadra a baía de Santa Helena, e isso porque, em 1487 e 1488, com Bartolomeu Dias, passara muito ao largo na ida para o sul e de noite na vinda para o norte, pois os navios, em via de regresso, haviam largado do Cabo na manhã precedente (31). De tudo isto ressalta o fato bem concreto da latitude do Cabo ter sido determinada com exatidão mui próxima da verdadeira em 1488, por isso que, conforme verificação de Fontoura da Costa, na estimativa da distância a que a baía de Santa Helena demorava do Cabo, não errava o pilôto Pero de Alenquer em mais que uma légua.

Recordo-me de haver lido algures que a latitude do Cabo da Boa Esperança no mapa chamado de Cantino é de 33 graus Sul. A verdade, porém, é que, se atendemos ao irregular paralelismo das linhas do equador e dos trópicos resultante da contração operada no pergaminho durante o longo tempc da sua existência, tanto podemos achar 33 como 34 ou 35. Histórico é o fato de Bartolomeu Dias e os seus pilotos terem determinado para o Cabo uma latitude mui próxima da verdadeira em 1488, e se nos perguntamos qual o número exato que a exprimia, não andaremos errados buscando-o no livro de Duarte Pacheco Pereira, certo, como é, que Bartolcmeu Dias tocou na ilha do Príncipe quando velejava de torna-viagem para o norte e ali encontrou doente o autor do Esmeraldo, que por êle foi então transportado para Lisboa comc passageiro de ocasião (32).

Podemos bem conjeturar quais teriam sido os temas de conversação dos dois insignes mareantes durante o tempo em

\footnotetext{
(29). - João de Barros, Asia, edịção đe Lisboa, 1945, déc. I, liv. IV, cap. II, pág. 135.

(30). - Diário da Viagem de Vasco da Gama, eđiçāo do Pôrto, 1945, vol. I, pág. 10.

(31). $\rightarrow$ Thidem.

(32). - Joāo de Barros, ob. cit., déc. I, liv. III, cap. IV, pág. 94.
} 
que foram companheiros de viagem. O delineamento gergráfico da nova costa descoberta, os lugares em que Dias implantou os seus padrōes, as latitudes observadas nos vários pontos em que tocou, tudo estava patente à curiosidade do grande Duarte Pacheco no mapa preparado para elucidação de D. João II, e tudo isso êle não deixaria de rememorar quando escreveu o seguinte passo do seu livro:

"Não sem muita razão se pôs nome a êste promontório "Cabo de Boa Esperança", porque Bartolomeu Dias, que o descobriu per mandado del-rei D. João, que Deus tem, no ano de Nosso Senhor de mil quatrocentos e oitenta e oito anos, vendo que esta costa e ribeira do mar voltava dali em diante ao norte e ao nordeste, cuja rota fazia caminho da Etiópia sob-Epigto e dali pera o Sino Arábico, onde se mostrava e se esperava haver-se de descobrir a Ínđia, por esta causa lhe pôs nome "Cabo de Boa Esperança"; o qual se aparta em ladeza, do círculo da equinocial contra o polo Antártico, trinta e quatro graus e trinta minutos" (33).

Trinta e quatro graus e trinta minutos era, pois, a latitude atribuída ao Cabo por Duarte Pacheco e não é de crer que diferente tivesse sido a que Bartolomeu Dias, Janinfante, Pero Dias, Pero de Alenquer, Alvaro Martins e João de Santiago ali determinaram por alturas meridianas do sol em 1488. Por isso dizia Pero de Alenquer em novembro de 1497, depois de calculada a latitude da Angra de Santa Helena, que o mais que podiam "ser, seriam trinta léguas a ré do cabo".

$*$

Dizer que nas passagens citadas por mim do Diário da primeira viagem de Colon às Antilhas e do livro de Fernando Colon não estão em causa os pilotos mas sim os maririheiros e outros tripulantes, é falsear a terminologia dos textcs, é opor à objetividade de tais citações a sofística tergiversante de um pueril subterfúgio. $\mathrm{E}$ não menos enganosa e evasiva é ainda a pretensão de que o extrato feito por Frei Bartolomeu de las Casas do sobredito Diário não constitui testificação aceitável da impreparação dos navegadores espanhóis do século $\mathrm{XV}$ para a marinharia do mar largo. Esqueceu-se o douto relator que a prova concludente dessa impreparação nos é dada por um documento de origem régia - a Real Cédula

(33). - Esmeraldo, edição da Academia Portuguêsa da História, Lisboa, 1954, liv. III, cap. VII, pág. 183 . 
de nomeação do florentino Américo Vespúcio para o rargo de pilôto-mor da Casa de Contratación de Sevilha. E com um outro fato, de resto, se pode comprovar a justeza das passagens por mim citadas do referido Diário e do livro de Fernando Colon. E' o caso de Martin Alonso Pinzon, capitão de um dos navios - a caravela "Pinta" - que compunham a flotilha da primeira viagem de Colon às Antilhas, haver acompanhado o Almirante desde a ilha Espanhola até à altura dos Açores e depois ter ido parar a Baiona, na costa da Galiza, qundo o seu destino era Palos, na costa da Andaluzia.

Segundo o contra-almirante norte-americano Samuel Eliot Morison, Martin Alonso Pinzon, que se havia desgarrado do seu almirante na tempestuosa noite de 13 de fevereiro de 1493, não avistou os Açores. A "Pinta" entrou no pôrto de Baiona, perto de Vigo, justamente ao norte da fronteira portıguêsa, a umas 450 milhas de Palos e a mais de 5 graus de latitude ao norte do Cabo de São Vicente. Martin Alonso estava òbviamente convencido, como seu irmão, de que as caravelas navegavam nas proximidades da Madeira quando a tempestade as atingiu em 13 de fevereiro, e depois de passado o mau tempo tomou um rumo de nordeste com o qual errou o seu pretendido destino em algumas centenas de milhas. A data da sua chegada a Baiona não foi registada; mas como a "Pinta" prosseguiu a sua navegação enquanto a "Niña"- se demorava na ilha de Santa Maria, deve ter escapado ao ciclone que alcançou êste navio em 26 de fevereiro e deve ter entrado no seu imprevisto pôrto de arribada em um dos dias da última semana de fevereiro (34).

$\mathrm{E}$ aqui ponho ponto final na réplica que devia ao distinto. relator e crítico da minha comunicação. Se a sua sabedoria lhe sugere outras objeções ao meu arrazoado, desde já lhe declaro que pode considerar-se vitorioso, porque, pela minha parte, acaba aqui a nossa controvérsia.

Tratarei agora de citar as objeções críticas que me foram opostas pelo meu outro contraditor (35). São elas:

(34). - Cfr. S. E. Morison, The Admiral of the Ocean Sea, Boston, 1942, vol. II, págs. 3-4.

(35). - o crítico a que me refiro é o Eng. José Antônio Madeira, astrônomo do Observatório de Lisboa. Apresentou uma comunicação ao Congresso sob o título: "Estudo histórico-científico, sob o aspecto gnomônico, da figura radiada de pedra tosca suposta coeva do Infante D. Henrique, existente na sua antiga "Vila de Sagres". 
a). - $O$ ensino dos métodos de navegação praticados pelos navegadores henriquinos não eram exclusivo de uma hipotética escola náutica criada pelo Infante no Algarve. Ésses métodos ensinavam-se no Algarve, como também se ensinavam em Lisboa e em outras regiões maritimas do país.

b). - Ao contrário do que eu afirmara (!), os navegadores henriquinos não ignoravam o movimento diurno da Polar nem o número de graus a que a estrêla distava do polo. A prova é que Colombo se guiava pela Polar para saber quando a agulha nordesteava ou noroesteava.

c). - Não sabia quais as razões que me tinham levado a situar em Lagos a escola náutica criada pelo Infante. Gostaria, por isso, que eu lhe explicasse essas razões.

Nada mais me foi oposto pelo abalizado crítico ora em referência. E' pouco o que se dignou objetar em desfavor da minha tese, mas a êsse pouco também vale a pena responder.

Eu creio ter demonstrado de modo irretorquível que os método náutico-astronômicos dos pilotos henriquinos nunca antes haviam sido usados por outros quaisquer navegadores e, uma vez posta a questão neste pé, ocorre-me perguntar: surgiu o ensino dêsses métodos simultâneamente e por eclosão expontânea em tôdas as regiões marítimas de Portugal? Não, evidentemente, porque para o ensino de qualquer matéria nova são necessários professôres e êstes de algures tem de vir. Ora nós sabemos que Mestre Jácome de Maiorca, cosmógrafo, astrólogo e cartógrafo, veio para Portugal num dos oito anos seguintes ao do encôntro da ilha de Pôrto Santo por João Gonçalves Zarco, e, sabendo isso, ocorre ainda perguntar: não terá sido êsse Mestre Jácome, como diz João de Barros, um dos primeiros professôres dos pilotos henriquinos, visto que até então ninguém sabia fazer navegação de altura? E não terá sido por via de alguns dêstes últimos que os referidos métodos vieram a generalizar-se entre outros pilotos não dependentes do Infante? Eu creio que sim, e creio também que os métodos de navegação henriquinos constituiam um segrêdo nacional impôsto de cima para baixo com a juramentação apropriada. Se assim não fôsse, pouco seria o tempo que levariam a divulgar-se entre estrangeiros e, sobretudo, entre os andaluzes, os quais, no tempo de $\mathrm{D}$. Afonso $\mathrm{V}$, e só com a sua prática de naveżação costeira, se erigiram em concorrentes dos portuguêses no tráfico da Guiné. Dir-se-á que o Infante não se coibiu de aliciar para as viagens da Guiné os "mercadores" Antonioto Usodi- 
mare, genovês, e Luís de Cadamosto, veneziano (36). Consideremos, porém, que Usodimare e Cadamosto foram à Guiné em navios portuguêses, com pilotos portuguêses e tripulações portuguêsas. Cadamosto pôde dar-se conta de que a Polar era o astro de referência para o distanciamento em latitude, mas, pelo que se depreende dos relatos das suas duas "navıgações", não conhecia qualquer regimento do norte nem tampouco o instrumento com que os pilotos tomavam a altura da estrêla.

Não é êrro dizer que, na sua primeira viagem à Guiné, Cadamosto não intervinha de modo nenhum na manobra e condução do navio. A caravela em que seguiu era propriedade do Infante o patrão encarregado do seu comando chamava-se Vicente Dias e era natural de Lagos. A Cadamosto, portanto, não há outra função a atribuir senão a de proprietário da mercadoria transportada para negócio. Nesta qualidade convinha-lhe atingir os locais da Guiné onde mais pudesse ganhar com o que levava, e êsses locais seriam aquêles em que houvesse mais ouro para troca e menos experiência de trato, por conseguinte mais longe, em paragens ainda não atingidas por outros navios, como queria o Infante. Torna-se, pois, evidente que a qualidade sobredita não lhe conferia outro direito que não fôsse o de requerer ao capitão da caravela a demanda dos pontos da costa que se lhe afigurassem de comércio mais lucrativo. Durante os percursos seguidos pelo navio ou nos locais onde tocavam, as alturas da Polar, quando necessárias, seriam observadas pelo capitão e pelo pilôto enquanto êle dormia ou permanecia em terra hospedado pelos chefes indígenas, nunca lhe dando ocasião a que pudesse formar idéia exata de como isso se fazia.

Note-se, aliás, que a caravela em que Cadamosto fêz a sua primeira viagem à Guiné só navegou isolada até ao Senє:gal . Ali juntaram-se-lhe mais duas, como se lê no seguinte passo da relação do veneziano:

"...determinei de navegar mais adiante, passar Cabo Verde, ir descobrir países novos, e provar minha ventura; sendo coisa, que antes da minha partida de Portugal tinha ouvido ao Sr. Infante (como pessoa que de tempos a tempos era avisada das coisas destas terras dos

(36). - Em o Manuscrito "Valentim Fernandes", edição da Academia Portuguê sa da História, Ltsboa, 1940, pág. 73, lề-se:

"Ano 1455 - Foy descuberto ho ryo de Gambia per... criado do Iffante, sendo cõ elle dous mercadores cada hum cõ sua caravella .s. hum genoves chamado Antomotto, e o venezlano chamado Luys de Mosto". (O sublinhado é meu). 
Negros), que entre outras informações que tinha, era uma, que não muito longe dêste primeiro Reino do Senegal, mais adiante se achava outro Reino, chamado Gâmbia: no qual, diziam os Negros que tinham vindo a Espanha, se achava grande quantidade de ouro, e que os cristãos que ai aportassem, voltariam ricos. Pelo que movido da cobiça de achar êste ouro, e também para ver coisas novas; desembaraçado de Budomel, fui para a minha caravela. E estando para me fazer à vela para partir daquela costa; eis que uma manhã apareceram duas velas ao mar, as quais avistando-nos a nós, e nós a elas, sabendo que não podiam ser senão Cristãos, viemos à fala; e ouvindo que um dos ditos Navios era de Antoniotto Usodimare, Gentil-homem Genovês; e o outro de alguns Escudeiros do Sr. Infante; os quais, de comum acôrdo, tinham feito conserva para passar Cabo Verde, provar sua ventura, e descobrir coisas novas; achando-me eu também com aquêle mesmo propósito, me puz em sua companhia, e com uma só vontade, tôdas as três Caravelas dirigimos o nosso rumo para o dito Cabo" (37).

Assim temos, pois, os nobres Cadamosto e Antoniotto Usodimare a navegarem "de conserva" com a caravela dos "Escudeiros do Sr. Infante". A exploração subseqüente passou a ser dirigida por êstes últimos pois, segundo Valentim Fernandes, o rio Gâmbia foi descoberto em 1455 por um criado do Infante, sendo com êle, o genovês Antonioto e o veneziano Luís de Mosto, cada um em sua caravela (38). Assim não tinha:n os mareantes companheiros do genovês e do veneziano que ocuparse com os problemas da navegação, porquanto o seu papel outro não era que o de seguir o navio-guia. Fato é que do alturas mui pouco sabia Cadamosto e, decerto, nunca elas foran tomadas na sua presença pelos pilotos. Ele alude unı véz à altura da Polar, mas não em têrmos de métrica astronômica, pelos quais se pudesse deduzir a latitude. As duas palavras são estas:

"Nos dias que estivemos sôbre a embocadura dêste rio [Gâmbia] não vimos mais que uma vez a estrêla do Norte: aparecia muito baixa sôbre o mar, e era necessário para a ver estar o tempo muito claro, parecendo

\footnotetext{
(37). - Apuđ Vitorino Magalhães Godinho, Documentos sôbre a Expansão Portuguêsa, vol. III, Lisboa, 1956, págs. 163-164.

(38). - O rio Gâmbia já anteriormente havia sido atingido por outros caravelistas do Infante, mas o que importa 'fixar é a subalternidade dos navios em que lam Antonioto Usodimare e Cadamosto aos "Escudeiros do Sr. Infante": Seria, allás, inadmissivel que os portuguêses aceitassem um papel subalterno perante estrangeiros que faziam a sua primeira viagem à Guiné.
} 
levantada dêle sòmente coisa de uma lança de altura" (39).

$\mathrm{Na}$ segunda "navegação" que Cadamosto, realizada em 1456, foram três as caravelas que formaram a frota da viagem. Numa ia o veneziano, noutra Antoniotto Usodimare e na terceira, armada pelo Infante, um qualquer capitão pcrtuguês cujo nome ficou no olvido, mas a quem òbviamente coube o encargo de guiar a expedição. Também desta vez alude Cadamosto à altura da Polar na região mais longínqüa a que chegou. Pouco é, porém, o que diz, e com êsse pouco só é possível concluir que os pilotos seus companheiros jamais mediram a altura da estrêla na sua presença. Elle não diz mais do que isto:

"Estivemos dois dias sôbre a embocadura dêste rio [Gêba], e a estrêla do Norte mostrava-se aqui muito baixa" (40).

Sôbre esta segunda "navegação" de Cadamosto e Antonoto Usodimare estão longe de serem concordes os pareceres dos críticos históricos. Para uns não passa ela de pura invenção; para outros não há por que rejeitar a veracidade da narrativa do veneziano. Eu, que sou apenas um curioso à margem dos historiógrafos dos descobrimentos, julgo que a mesma "navegação" talvez não seja totalmente inventada. O que ela tem de falso, com certeza, é o descobrimento de quatro ilhas do arquipélago caboverdiano. Bem aparente é essa falsidade, posto que o navio de Cadamosto fazia parte de um grupo de três, todos com comandos independentes, e nerhum dos seus capitães deu notícia ao Infante ou ao rei D. Afonso $\mathrm{V}$ de tão importante achado. A donatária da ilha de Santiago, uma das que Cadamosto diz ter descoberto, foi concedida ao genovês Antônio de Noli em 1460 ou pròximamente, por ter sido êle "o primeiro que a dita ilha achou". Certo é que êste genovês teve um companheiro no achamento do grupo sud-oriental das ilhas de Cabo Verde e êsse companheiro é que poderia haver figurado nos documentos oficiais romo primeiro descobridor se o Noli não se lhe tivesse adiantado na chegada a Portugal. Não era êle, porém, veneziano nem se

(39): - Apud Vitorino Magalhảes Godinho, ibidem, pág. 174.

(40). - Toidem, pág. 209. 
chamava Luís de Cadamosto; era o português Diogo Gomes de Sintra, o mesmo que disse ao alemão Martin Behaim (41):

"eu tinha um quadrante quando fui a estas partes, e escrevi na tábula do quadrante a altura do polo ártico, e achei isso melhor do que a carta. E' certo que na carta aparece o caminho de navegar, a rota do navio, mas muitos erros juntos nunca levam ao propósito principal".

Sôbre êste passo da De prima inventione Guinea. escreveu o Dr. Luciano Pereira da Silva (42):

"Diogo Gomes, quando foi para aquelas partes, levava um quadrante; escreveu nêle a altura do Norte, e achou-o melhor que a carta de marear. Do modo como se exprime depreende-se que aquilo que escreveu no instrumento o valorizou para o uso que dêle queria fazer. Parece-nos para isto bastante elucidativo o trecho seguinte, que se encontra no Reportório dos tempos de Valentim Fernandes, subordinado ao título "De como se há de navegar pelo quadrante":

"Partindo algum de Lisboa pare mentes onde lhe cai a chumbada.s. em qual grau e põe ali um sinal sobre o quadrante, em tal tempo quando as estrelas das guardas estão leste oeste com a estrela do norte. E depois, um dia, ou dois, ou mais, quando quer que quiserdes no mar saber quanto o vosso navio esta diferenciado de Lisboa, vereis a quantos graus cai então o chumbo, ou de um cabo ou do outro de vosso primeiro ponto... E assim de todolos lugares fareis onde quer que vos partirdes, como se diz agora de Lisboa".

"Diogo Gomes deve ter assim notado no quadrante os graus da altura da Polar em Lisboa, correspondentes a uma ou mais posições das Guardas. Era um modo de escrever um Regimento do Norte, eqüivalente ao que resume a roda do Regimento de Munique, embora numa fase anterior mais simples. Achou o quadrante melhor que a carta, porque nesta, é certo, se vai traçando a derrota pelos rumos percorridos e distâncias estimadas, mas os erros vão-se acumulando, e por isso acrescenta: "certum est quod in carta videtur via marinandi, sed semel errata nunquam redeunt ad primum propositum". Vendo que a latitude determinada com o instrumento de altura era diferente da latitude resultante da derrota marcada na carta, prefere a primeira, reconhecendo os defeitos do

(41). - De prima inventione Guinea, trad. port. de Gabriel Pereira, publ. no Boletim da Sociedade de Geografia de Lisboa, 17a. série, 1898-1899, n.0 5, pág. 286.

(42). - Obras Completas, vol. II, Lisboa, 1945, págs. 294 a 296 : 
processo de navegação por distâncias estimadas e rumos, de que adiante nos ocuparemos.

"Na relação de Diogo Gomes de Sintra encontra-se a primeira referência ao uso do quadrante para a medição da altura dos lugares pela Estrêla do Norte. Isto não significa, porém, que êle fôsse o primeiro navegador português que tal fizesse, nem êle isso afirma.

"Já nos Libros del saber de astronomia (Tomo II, pág. 276) se encontra, entre os capítulos dos Libros del astrolabio llano, um que trata "De saber la ladeza de la villa por las estrellas fixas". Manda-se tomar alguma das estrêlas que estão cêrca do polo setentrional, quando ela for na sua maior altura, e quando na altura mínima. A média das duas alturas observadas é a latitude do lugar. Entre as estrêlas circumpolares especializa-se "la estrella a que dizen Algedi, que es en cabo de la cola de la orsa menor", a qual é a mesma Estrêla do Norte dos nossos navegadores".

Advirto, de passagem, que êste último tópico dos Lihros del saber de astronomia el réy $D$. Alfonso $X$ de Castilla constitui uma boa prova de que o movimento diurno da estrêla Polar era conhecido na côrte portuguêsa desde o século XIII, pois que pelo mesmo rei castelhano foi oferecido a seu neto D. Diniz de Portugal uma cópia da referida obra. E' isto mais um argumento contra os que negam aos pilotos henriquinos a técnica da navegação por alturas. Não é conhecido cualçuer exemplar do regimento do Norte por êles usado, mas o transporte de povoadores e mercadorias para as ilhas da Madcira e Açores não se fazia ao acaso. Aconselhável era, de resto, o resguardo cauteloso dessa técnica de navegação, e, $s \cdot$ aos pilotos se exigia o compromisso de não a divulgarem, o intelêsse dêles era não registar em papéis o que podiam guardar na memória.

Há quem tenha por assente que o trecho antes transcrito da relação de Diogo Gomes de Sintra deixou de ter qualquer significado válido depois do estudo crítico que lhe dedicou o falecido Prof. Dr. Duarte Leite (43). Em minha modesta opinião não deixa o eminente professor de estar com a verdade quando atribui ao próprio Martin Behaim a autoris do passo, que cita (44), relativo a Ptolomeu, mas erra ao pretender

(43). - Vide História dos Descobrimentos, coletânea de esparsos, vol. I, Lisboa, 1958, págs. 375 a 381 .

(44). - Ibidem, pág. 380 . 
que é de Diogo Gomes a passagem em que se diz que nc cabo Verde começa a linha equinocial, porque ali são sempre iguais dias e noites, no inverno como no verão. Considera o insigne historiógrafo que a altura da Polar nunca desce no cabo Verde de $10^{\circ}$ e que quem dispusesse dum quadrante nunca poderia imaginar êsse cabo no equador ou sequer na sua proximidade. Que isso é o bastante para convencer que Diogo Gomes. que várias vêzes deve ter passado pelo cabo, jamais se serviu de tal aparelho, pois totalmente desconhecia a latitude clêsse ponto da costa africana. Ora eu pergunto: será de aceitar como bom êste razoamento do professor Duarte Leite?! Diogo Gomes não precisava de medir a altura da Polar no cabo Verde para saber que êsse lugar não estava debaixo da equinocial! No cabo Verde mostrava-se a estrêla bem elevada sôbre o horizonte aos olhos de tôda a gente que por lá passava e mais não era preciso para se saber que o equador ainda ficava muito longe para o sul! Mas pergunto ainda: se o Dr. Duarte Leite reconhece que Diogo Gomes deve ter passado várias vêzes pelo cabo Verde, por que atribui a êle, e não a Martin Behaim, "a definição da equinocial pela duração do dia"?! Seria Diogo Gomes tão obtuso que não soubesse notar a diferença entre a duração dos dias e das noites nos vários locais da costa africana que percorreu e consoante as quadras do ano em que por êles passou?! Atribuindo a Diogo Gromes tão grande tolice não pretendeu o eminente professor desacreditar e dar como nulos os conhecimentos náutico-astronômicos dêsse navegador para melhor fazer crer que a referência ao quadrante constante da sua relação é uma invencionice ali intercalada por Martin Behaim, que a escreveu?! Pois que me perdoi a alma do Dr. Duarte Leite se na minha pequenez e insignificância me atrevo a pugnar pelo inverso. No tempo em que Martin Behaim viveu em Portugal já os nossos navegadores se serviam do astrolábio para determinar a altura do polo, mas no passo da relação de Diogo Gomes impugnado pelo Dr. Duarte Leite não é um astrolábio, mas um quadrante, o instrumento que êle diz ter possuído. Ora isto faz-me tomar o referido passo como da autoria do discutido caravelista, porque no seu tempo só a Polar era o astro utilizado pelos navegadores portuguêses e o quadrante era o único instrumento com que então lhe mediam as alturas.

A hipercrítica do Dr. Duarte Leite nem sempre o conduziu a conclusões acertadas. Elle diz que na época em que Behaim escreveu a relação de Diogo Gomes "mediam-se as 
alturas da Polar com astrolábio náutico e quadrante" (45), mas a verdade é que, com um astrolébio, ninguém é capaz de medir no mar a altura de uma qualquer estrêla. $O$ astrolábio náutico usava-se já em tal época mas para medir as alturas meridianas do Sol e era, como é óbvio, um instrumento bem conhecido de Behaim. Este, porém, embora tendo adulterado a relação com uma ou outra sentenças de sua autoria, não fantasiou para Diogo Gomes a prática de corrigir pelo Sol o êrro latitudinal da navegação estimada. Diogo Gomes possuiu, não um astrolábio, que para nada lhe serviria sem o respectivo regimento, mas um quadrante, e contra isto nada pode a sofística do falecido professor Duarte Leite, que atribuiı àquêle mareante uma tôla sentença de Behaim para invalidar um passo irrecusável da sua relação e negar aos caravelistas p.ortuguêses do tempo do Infante a técnica da navegação por alturas.

\section{$*$}

Não sei como ao ilustre crítico a quem ora respondo ocorreu a idéia de que eu afirmara não terem os navegadores henriquinos conhecimento do movimento diurno da Polar! Mas o que eu sei e posso dizer é quanto me surpreendeu o argumento de que tal conhecimento se prova com o fato de Colon recorrer aos azimutes da Polar para saber quando a agulha nordesteava ou noroesteava! Não, senhor! Este argumento é puro contra-senso mesmo para o caso que eu tivesse feito uma tal afirmação! A primeira viagem espanhola de Colon às Antilhas data de 1492-1493, por conseguinte bastante depois da época em que viveu o Infante, e em 1487 já Bartolomeu Dias teria levado consigo um regimento manuscrito do astrolábio e do quadrante, posto que por alturas meridianas do Sol medidas com astrolábio determinou êle a latitude do Cabo da Boa Esperança em 1488. De notar é, para mais, que o afastamento máximo da referida estrêla para cada lado do polo era então de cêrca de 3,5 graus na latitude das Canárias e desde que a declinação magnética superasse êsse número para leste ou oeste do meridiano, tornava-se bem aparente o nordestear ou nornestar da. agulha mesmo para pessoas que tivessem o astro como marca fixa do Norte. O almirante norte-americano Samuel Eliot Morison julga ser êste o caso de Colon e diz que êste navegador descobriu por si próprio o movimento diurno da Polar, pois notara que, do anoitecer ao amanhecer, não era constante a va-

(45), - Ibldem, pág. 381. 
riação das suas agulhas em relação à estrêla (46). Segundo o. mesmo historiógrafo, os homens do mar - como Colcn - - tiveram como certo durante séculos que a estrêla do Norte marcava o norte verdadeiro (47). Erra, porém, o almirante Morison nestas suas asserções historiográficas, porque a verdade é que Colon conhecia o regimento do Norte. $\mathrm{Na}$ relação da sua terceira viagem, ao referir algumas das alturas da estrêla por êle medidas com um quadrante, sempre menciona a pcsição das Guardas no momento da observação. Há decerto exagerada discordância numa ou noutra das alturas por êle obíidas. em uma mesma noite e nem sequer indica as correções que lhes. teria de aplicar para obter a latitude, mas tudo isso se explica e justifica: Colon não queria que, com tais ensinamentos, se. pudessem elevar à sua craveira de navegador oceânico aquêles que em Espanha se aprestavam para lhe mover cuncorrência, tais os Alonso de Hojeda, Vicente Pinzon, Diego de Lepe e outros. Pois não foi com o mapa feito por êle na sua terceira viagem que Alonso de Hojeda demandou a regiño venezuelana de Pária em 1499? Tivesse Colon explicado como se determinava a latitude pela altura da Polar e logo o famigerado bispo de Burgos, Juan Rodriguez de Fonseca, se encarregaria de transmitir o método a todos os espanhóis que então se preparavam para explorar a costa setentrional do continente. sul-americano.

E nada mais julgo necessário dizer em resposta à seggunda. objeção do crítico ora em referência. Tratarei, portanto, de explicar as razões que me levaram a situar em Lagos a escola. náutica do Infante.

A escola de cosmografia, cartografia e marinharia instituída e mantida pelo Infante D. Henrique em terra algarvia é, em meu parecer, um fato indubitável. Essa escola não existiu em. Sagres nem na aldeia da Raposeira, porque estas duas localidades foram, por assim dizer, ignoradas do Infante até ao fim do terceiro quartel da sua vida. A ter existido, portanto, a referida escola, mas não em nenhuma de tais localidades, há que apontar Lagos como local em que esteve instalada.

Lagos foi a escala histórica de quase tôdas as expedições. guerreiras lançadas à conquista das praças costeiras de Marrocos. Em 1415 por lá passou a que ia à tomada de Ceuta, e,

(46). - Cfr. ob. ci.t, vol. I, pág. 271.

(47). - Ibidem. 
como desde então o Infante D. Henrique ficou com o encargo de prover ao abastecimento e defesa dessa cidade marrog:xina. fêz de Lagos, desde logo, a base operacional dos navios que mantinham livres de inimigos as rotas de acesso à nova possessão. "Depois que a dita cidade foi tomada", diz Zurara (48). o Infante

"continuadamente trouxe navyos armados no mar contra os infiees, os quaaes fezerom muy grande destroyçam na costa daalem e daaquem, de guisa que o seu temor poinha em segurança todallas terras vezinhas do mar da nossa Espanha, e ainda a mayor parte dos mercadores que trautavam do levante para o poente."

E' evidente que o mar aqui mencionado por Zurara é o que medeia entre o litoral do Algarve e Andaluzia, por um lado, e a costa de Marrocos, pelo outro. Aquêle cronista não cita as bases operacionais dos navios a que alude, mas uma delas era Ceuta - cujo acesso havia que assegurar - e a outra era Lagos, perto da extremidade poente do litoral algarvio. Estratègicamente nada de melhor se oferecia no Algarve, e I a gos tinha por si a amplidão da sua baía e o remanso acolkiedor dos seus ancoradouros, com um rio onde se podia acurir a tôdas as necessidades dos navios.

Sôbre as navegações africanas do período henriquino compreendido entre a tomada de Ceuta e a passagem do Bojador, escreveu o meu venerando amigo Dr. Francisco Fernandes Lopes (49):

"A D. Henrique, que fôra indubitàvelmente a alma da feliz expedição, manda D. João - seu pai -, em seguida, de Estremoz, em 18 de fevereiro de 1416 , que se entreguem os dinheiros precisos para a defesa de Ceuta, com cujo encargo ficara. Assim, logo desde o regresso, teria $\mathrm{D}$. Henrique trazido armada no mar, permanentemente, para tal fim, e (se não houve confusão da memória de Diogo Gomes ou de quem o informou), a ela pertenceriam. (se não já mesmo à armada que regressara da conquista), aquelas "algumas caravelas" que, por tormenta, em 1415 talvez ainda, sob o comando de D. João de Castro, teriam ido parar às Canárias, encontrando na. volta as grandes correntes de mar, entre as ilhas, que muito haviam custado a vencer; fato êste que, narrado ao

(48). - Crônica dos Feitos de Guiné, edição da Agência Geral do Ultramar, vol. II, Lisboa, 1949, cap. V, pág. 27.

(49). - A Figura e a Obra do Infante D. Henrique, Lisboa, 1960, págs. 23-24 e: 36-37. 
Infante, o teria incitado a mandar no ano seguinte "um cavaleiro nobre, Gonçalo Velho, para além das Canárias, ao longo da beira-mar, desejando saber a causa de tão grande corrente" - "a primeira expedição científica dêste gênero, de que há memória" (Edgar Prestage).

"D. Henrique que, sem dúvida devidamente autorizado por seu pai, prosseguira na sua porfia, havia 15 anos desde antes de ultrapassado o cabo Não - o nec plus ultra da tradição marítima inveterada - acabara de enviar nesse ano de 1433, numa barca, a passar o cabo Bojador, o algarvio Gil Eanes, natural de Lagos, seu criado de moço pequeno, o qual, como os dos anos das tentativas anteriores, não conseguiu afinal passar das Canárias, trazendo, como de costume, alguns cativos para forrar as despêsas da navegação...

"Não se sabe se fôra de Lagos que Gil Eanes partira, como igualmente se ignora se foi do Algarve ou de Lisboa que terá partido algum dos navios dos anos de porfia.

"Certo é, porém, que desde muito antes as caravelas pescarescas de todo o Algarve têm ido não só à pesca da baleia no Atlântico, mas à de vários peixes do mar alto na costa atlântica de Marrocos, e que com Marrocos ficara o Algarve em relações de tôda a espécie desde a tomada de Faro (1249), defendendo-se os algarvios da pirataria tradicional por suas próprias fôrças... Assim, teria o Infante encontrado já criado aqui o ambiente próprio e a gente preparada, sabendo ir e voltar dos mares atlânticos, tendo pois aproveitado noutro sentido e atividade e sabedoria do mar dos algarvios..., e por isso teria acabado por vir assentar arraiais no Algarve, fazendo de Lagos o grande pôrto de armamento".

Do pequeno repositório documental que é o interessante livrinho do Dr. Jordão de Freitas, intitulado "A vila e fortaleza de Sagres nos séculos XV a XVI", transcrevo a seguinte passagem:

"A região do Algarve de princípio mais freqüentada por $D$. Henrique deve ter sido a vila de Lagos, onde sabemos que habitou casas suas próprias. Aqui vivia a quando das côrtes gerais de Leiria (janeiro de 1438), às quais aliás não assistiu. Em Lagos residia em junho e setembro de $1438 \longrightarrow$ segundo refere o cronista Rui de Pina; bem como cinco anos depois, quando lá fêz armar uma caravela em que mandou Nuno Tristão com outras algumas gentes e principalmente de sua casa conforme se lê em Azurara. De Lagos conheço três cartas suas escritas no ano de 1444: uma datada de 8 de 
setembro, a segunda de 5 de dezembro e a terceira do dia seguinte. Aí estava em 1445 - quando Lançarote lhe requereu licença para, com outros, ir sôbre os mouros da Ilha de Tider a fim de vingar a morte dos companheiros de Denis de Grã e de Gonçalo de Sintra. Aí vivia ainda em 1446 - quando seu irmão o Infante D. Pedro lhe escreveu pedindo que fôsse a Coimbra para armar cavaleiro seu filho primogênito D. Pedro de Portugal, que era então condestável do Reino.

"Deixando a habitação de Lagos, D. Henrique foi residir para a Raposeira - aldeia situada a oeste daquela vila, légua e meia a nordeste da angra de Sagres, pela terra dentro; povoação vizinha da Aldeia do Bispo, na mesma altitude da próxima Tôrre d'Aspa. Na Raposeira (como vimos, pág. 12), tinha o Infante "pousadas", "onde pousava" em 23 de junho de 1446. De aqui se conhece uma sua carta datada do dia 25 de outubro de 1452. Aqui "habitava muito de boamente" nos fins de 1454, "por ser sítio muito remoto do tumulto das gentes e apto para a contemplação dos seus estudos", como se lê em Cadamosto.

"Só mais tarde - quando edificada já então a sua vila de Terçanabal ou vila do Infante - aqui passou a residir. Aqui assistiria já quando da expedição a Alcácer Ceguer, que partiu de Lisboa em 1458.

"Advirta-se que em 1433 - ano decorrido o qual, segundo Duarte Pacheco, o Infante D. Henrique se apartou com sua casa para o Algarve - já se achavam redescobertas e ocupadas as ilhas do arquipélago da $\mathrm{Ma}-$ deira, redescobertas e abordadas também algumas das do arquipélago dos Açores. O mesmo há que considerar em relação àquêles "12 anos" passados em sucessivas viagens feitas à costa ocidental da África a que alude Azurara no capítulo IX da sua Crônica de Guiné, referindo-se aos navios e mareantes para ali continuamente enviados por $D$. Henrique até ao ano em que a barcha de Gil Eanes dobrou o Cabo Bojador.

"Atenda-se também a que já então (1415-1433) teria vindo para Portugal a célebre cartógrafo Jaime de Malhorca, de quem nos fala Duarte Pacheco, num outro capítulo do seu Esmeraldo" (50).

Com êstes dados podemos bem ter por assente que o interêsse do Infante pelo Algarve se centrou de comêço e principalmente na então vila de Lagos. E por que mudou o Infante a sua residência efetiva para a vila de Lagos e não para qualquer outra região marítima do país? Sim, porque não

(50). — Ob. cit., págs. 79 a 83 . 
há efeito sem causa! Por que fêz êle de Lagos o entrepôsto das mercadorias da Guiné e o pôrto de armamento dọs navios mandados por êle ao descobrimento do litoral africano do Atlântico? Diz o Dr. Fernandes Lopes que não se sabe se foi de Lagos que Gil Eanes partiu em 1433, mas sabido que êsse navegador era natural de Lagos e que o Infante para esta vila foi residir em 1433, segundo o dizer de Duarte Pacheco, não constituirá isto por si só uma indicação de que o mesmo Gil Eanes ali iniciou as suas viagens de 1433 e 1434? Vejamos, aliás, que em 1433 êle trouxe alguns cativos das Canárias e que o mesmo costumava ser feito pelos que tentaram ultrapassar o Bojador nos anos anteriores. Onde se desembarcavam e vendiam êsses cativos? Eu creio que a resposta para esta interrogação se encontra no capítulo XVIII da Crônica dos Feitos de Guiné, no qual diz Zurara que os presos trazidos de Africa pelos que lá foram antes de Lançarote se "descarregavam em Lagos". Um fato, porém, sobreleva estas considerações e ésse é o do Infante ter estabelecido em Lagos o pôrto de armamiento dos navios dos descobrimentos e o entreposto das mercadorias da Guiné. Por que o fêz? Por ter ido para lá morar, dir-se-á. Mas por que escolheu êle precisamente a vila de Iagos para local da sua residência e não qualquer outro pôrto de tcdo o litoral português? Há de haver uma causa que a isso o tivesse movido; e que outra melhor se poderá encontrar senão a de ter sido Lagos a base operacional dos "navyos armados" que êle continuadamente trouxe no mar contra os infiéis depois da tomada de Ceuta e dos que enviou durante doze anos, pelo menos, para tentarem a passagem do Bojador? Porque dêstes fatos não há que duvidar. Elles são testificados pelo seguinte passo do capítulo XLIX da Crônica sobredita:

"Onde avees de saber que Lançarote, aquelle cavaleiro, almoxarife de Lagos, juntamente com os juízes, e alcaide, e officiaes da vereaçom daquella villa, chegarom ao Iffante em nome de todollos principaaes do lugar, fallando lhe em esta guisa: Bem sabe a vossa alteza como os moradores desta nossa villa, depois que Cepta foe tomada ataa o presente, sempre serviram e servem com seus corpos e navyos na guerra dos Mouros, por serviço de Deus e delRey nosso Senhor. E ainda nos tempos dos outros Reis, quando a costa deste regno era seguida dos Mouros, os nossos navyos eram os primeiros que armavam contra elles, segundo se acha per scripturas, e per antiigas memoryas dhomens de grandes idades. Agora, senhor, despois que vossa mercee ordenou de buscar esta 
terra de Guinee, bem sabees como em este lugar fizestes a mayor parte de vossas armações, onde vos foe feito todo aquelle serviço que em nossas possanças pode saber."

Lagos foi, pois, o pôrto desde sempre eleito pelı Infante para base de operações contra os mouros e para o armamento dos navios mandados explorar a costa africana além do Cabo Näo, e os chamados "anos de porfia" devem-se contar desde 1419, o mais tardar - posto que, segundo Zurara (51), quando Joào Gonçalves Zarco e Tristão Vaz Teixeira encontraram a ilha de Pôrto Santo já iam encaminhados "como fôssem em busca de terra de Guinee" - , até ao ano de 1434, num primeiro período que vai de 1419 a 1422, assinalado pelas primeira‘' viagens de Zarco e Tristão Teixeira ao grupo insular da Madeira, e um segundo começado em 1422, que abrange os "doze annos continuados", durante os quais "o Iffante" mandou "em cada hum anno" "seus navyos, com grande gasto de suas rendas" (52), para tentarem a passagem do Bojador.

Convencido de que estou com a verdade, dire ainda que o funcionamento em Lagos da escola náutica do Infante constituiria para êle um outro motivo de atração. Era obra sua e condição sine qua non do êxito da sua emprêsa marítima. Em Lagos estava a escola ao abrigo de curiosidades estranhas, porque não é de admitir que o Infante quisesse ver divulgados entre os navegadores estrangeiros os ensinamentos técnico-náuticos nela ministrados aos seus caravelistas. Por isso tarrbém se passava como se ela não existisse, mas o Infante fizera vir de IMaiorca aquêle Mestre Jácome cosmógrafo, astrólogo e cartógrafo, e os pilotos henriquinos sabiam como encontrar as ilhas dos grupos da Madeira e dos Açores quando para lá transportavam povoadores e mercadorias, ou quando por elas queriam passar na ida ou na vinda das suas viagens africanas, e não saberiam menos acrescentar nos mapas que levavam as novas terras que iam descobrindo.

Talvez se me pergunte onde estão os documentos que comprovam a existência dessa escola em Lagos no tempo do Infante. Que os procure quem os julgue necessários, porque para mim são bastantes as razões que apresento. A História não se faz sòmente com documentos escritos mas também corm fatos indesmentíveis, como são os do povoamento e exploração das ilhas da Madeira e dos Açores. O que importa é analisar

(51). - Ob. cit., cap. LXXXIII, pág. 360.

(52). - Zurara, ob. cit., cap. VIII, pág. 50. 
êsses fatos à luz do inerente condicionalismo náutico-astronômico, condicionalismo que deu origem a uma técnica de navegação sui generis, jamais praticada no Mediterrâneo ou no Atlântico antes da época do Infante.

O meu amigo Dr. Francisco Fernandes Lopes anda errado se pensa que "a sabedoria do mar dos algarvios" nos primeiros quatro lustros do século XV diferia em algo da dos marítimos andaluzes. As viagens regulares para o grupo insular da Madeira começaram em 1420 - ou talvez mais exatamente em 1425 (53) -, e não consta que os algarvios alguma vez lá tivessem ido em época anterior. Quem vai à pesca e se afasta uma ou duas centenas de milhas da costa portuguêsa - o que já é muitíssimo para pescadores vulgares - pode muito bem voltar ao ponto de partida só com o auxílio de uma agulha; mas demandar um grupo de ilhas isolado no mar largo é coisa muito diferente.

$\mathrm{E}$ aqui ponho têrmo ao meu arrazoado oferecendo à ponderação do meu segundo contraditor as seguintes considerações:

$\left.1 .^{\circ}\right)$. - Depois da tomada de Ceuta ficou o Infante D. Henrique com o encargo de prover ao abastecimento e defesa da mesma praça;

2.0). - Lagos foi a base operacional dos navios que mantinham livres de inimigos as rotas de acesso a Ceuta;

3. ${ }^{\circ}$. - - Esses navios corriam a costa de Granada e a de Marrocos desde Ceuta até ao Cabo Não ou pouco mais longe, até às Canárias, raziando o que podiam e trazendo cativos para venda ou resgate;

$\left.44^{\circ}\right)$. - Foi num dêsses navios e no decurso de tais andanças, que João Gonçalves Zarco e Tristão Vaz Teixeira encontraram, em 1419, a ilha de Pôrto Santo, talvez em bordada do Cabo Não para noroeste, a contornar o "tempo (vento) contrario" a que alude Zurara (54);

5. ${ }^{\circ}$. - - Antes do povoamento das ilhas de Pôrto Santo e da Madeira ninguém possuia as habilitações necessárias para demandar com segurança e acêrto quaisquer ilhas do mar largo;

$6^{\circ}{ }^{\circ}$. - - As viagens de povoamento e comércio para a Madeira e Açores não se faziam ao acaso;

7.0). - Essas viagens constituem prova evidente e irrecusável de que a navegação por alturas começou a pra-

\footnotetext{
(53). - Em 16 de setembro de 1460, em carta concedendo o espiritual do grupo da Madeira à Ordem de Cristo, escreveu o Infante D. Henrique: "comecei de povoar a minha ilha da Madeira averá ora trinta e cínco anos, e isso mesmo a de Porto Santo...".

(54). - Zurara, ob. cit., cap. LXXXIII.
} 
ticar-se com o povoamento das ilhas de Pôrto Santo e da Madeira;

8. ${ }^{\circ}$ ). - Os pilotos portuguêses da navegação por a1turas não surgiram por geração expontânea entre gente que nada sabia de tal navegação;

9. ${ }^{\circ}$. - Esses pilotos foram, pois, ensinados em terra e em escola para o efeito instituída e mantida pelo Infante $\mathrm{D}$. Henrique;

10.0). - A vinda para Portugal de Mestre Jácome de Maiorca, cosmógrafo, astrólogo e cartógrafo, situa-se entre 1420 e 1427 (55);

11..$^{\circ}$. - Depois que o Infante ordenou de buscar a terra da Guiné, ou seja em 1419, se não antes, foi em Lagos que êle fêz a maior parte das suas armações para o efeito;

$\left.12 .^{\circ}\right)$. Lagos foi o primeiro lugar do Algarve escolhido pelo Infante para sua residência;

13. ${ }^{\circ}$. - - Nada sugere a existência da escola náutica do Infante em outra localidade do Algarve e Lagos tem por si todos os argumentos que se possam invocar e talvez até um ou outro documento dos muitos que jazem ignorados nos arquivos disseminados pelo país;

$14 .^{\circ}$ ). - Naturais de Lagos ou lá moradores foram muitos dos navegadores henriquinos, e de Álvaro Esteves diz Duarte Pacheco (56) que "foi o mais avantejado homem do seu ofício que na Espanha então houve" (57).

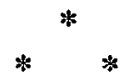

Dois contraditores se me opuseram no citado Congresso com as objeções a que acabo de responder. Mas a !um outro ainda terei de me referir para que não me acusem de haver omitido alguém, sobretudo quando êsse alguém é pessoa de alto nível mental e social como no presente caso. Trata-se do almirante espanhol Julio Guillen, autor distinto de vário trabalhos sôbre a cartografia e as viagens espanholas da época dos Descobrimentos, que, ao mesmo Congresso, apresentou uma comunicação versando o tema de "Las cartas de dos graduacicones en España".

O sr. almirante Guillen parece ter visto na minha comunicação -- que só conhecia pelo livro de resumos do Congresso e pelo pouco que dela ouvira ao relator - um mero intuito de

(55). - Cfr. Gonzalo de Reparaz (Filho), "Mestre Jácome de Malhorca" cartógrafo do Infante, separata da revista Biblios, Coimbra, 1930, págs. 44-46.

(56). - Esmeraldo, lív. II, cap. IV.

(57). - Espanha está aqui como expressão geográfica que abrangia tôda a Península Ibérica - Hispánia. 
diminuir e amesquinhar os navegadores espanhóis da época dos Descobrimentos, quando, afinal, o que se lhe impunha entender era que, certo, como é, haver sido instituído o ensino náutico no Algarve e em Sevilha para habilitar os pilotos das respectivas nacionalidades a conduzirem, com segurança e acêrto, os seus navios no mar largo, ao Algarve cabe indubitàvelmente a primasia de tal instituição, pois que já na terceira década do século $\mathrm{XV}$ praticavam os navegadores henriquinos os métodos de marinharia náutico-astronômica que só a partir de 1508 se começaram a ensinar aos pilotos espanhóis na Casa (de Contratación de Sevilha. E' isto, e só isto, o que ao sr. almirante Guillen cumpria entender e nenhum melindre haveria para o seu brio de espanhol se atendesse à consideração de que a História só é História quando retrata fielmente os acontecimentos do passado com suas determinantes, conseqüências e repercussões. Para mim, como para qualquer outro historiógrafo não enfeudado a convencionalismos farisáicos, é inteiramente legítimo invocar os documentos comprobativos dos fatos históricos que pretendo evidenciar ou esclarecer. Se êles desagradam a gregos ou a troianos, não vejo nisso motivo para que me abstenha de os citar. O pão com que me sustento não depende, graças a Deus, de tais considerações.

Embora consciente da minha insignificante pequenez, não passarei sem dizer que nutro grande simpatia e admiração pela distinta personalidade do nobre povo espanhol, povo honrado, brioso e altivo, cuja glória resplandece em tôdas as facetas do seu gênio criador. O seu lugar na História dos Descobrimentos e da Expansão Ultramarina não é, contudo, o mais cimeiro, pois que as suas realizações em tal domínio foram mera conseqüência das realizações portuguêsas.

ALEXANDRE GASPAR DA NAIA 